\title{
THE HISTORICAL ORIGINS OF THE PRIVILEGE AGAINST SELF- INCRIMINATION AT COMMON LAW
}

\author{
John H. Langbein*
}

The appearance of the privilege against self-incrimination - the guaranty that no person "shall be compelled in any criminal case to be a witness against himself" 1 - was a landmark event in the history of Anglo-American criminal procedure. Prior historical scholarship has located the origins of the common law privilege in the second half of the seventeenth century, as part of the aftermath of the constitutional struggles that resulted in the abolition of the courts of Star Chamber and High Commission. This essay explains that the true origins of the common law privilege are to be found not in the high politics of the English revolutions, but in the rise of adversary criminal procedure at the end of the eighteenth century. The privilege against self-incrimination at common law was the work of defense counsel.

From the middle of the sixteenth century, when sources first allow us to glimpse the conduct of early modern criminal trials, ${ }^{2}$ until late in the eighteenth century, the fundamental safeguard for the defendant in common law criminal procedure was not the right to remain silent, but rather the opportunity to speak. The essential purpose of the criminal trial was to afford the accused an opportunity to reply in person to the charges against him. Among the attributes of the procedure that imported this character to the criminal trial, the most fundamental was the rule that forbade defense counsel. The prohibition upon defense counsel was relaxed in stages from 1696 until 1836, initially

* Chancellor Kent Professor of Law and Legal History, Yale University. The Michigan Law Review was unable to consult certain sources that are cited to first editions in this essay. A $\dagger$ indicates a citation for which the Michigan Law Review consulted a later edition or secondary source to verify the source information. - Ed.

Throughout this paper, when drawing upon English and antiquarian sources, I have modernized and Americanized the spelling, but not in the titles of books and pamphlets. A forerunner of this essay was presented at the 1991 annual meeting of the American Society for Legal History, and to a Yale Law School faculty workshop. I am grateful for suggestions from those learned audiences and for advice from Christopher Allen, Akhil Amar, Albert Alschuler, David Brown, Richard Friedman, Paul Gewirtz, Abraham Goldstein, Thomas Green, Richard Helmholz, Richard Lempert, Michael Macnair, and William Twining.

1. U.S. CoNST. amend. V.

2. In "the reign of Queen Mary ... the earliest trials of which we have detailed accounts took place ...." 1 James Fitzjames Stephen, A History of the Criminal LaW of England 319 (London, MacMillan 1883). 
for treason, then for felony. Although persons accused of ordinary felony began to be allowed counsel in the 1730s, defense counsel did not become quantitatively significant until the $1780 \mathrm{s.}^{3}$

In the later eighteenth century and especially in the nineteenth century, a radically different view of the purpose of the criminal trial came to prevail. Under the influence of defense counsel, the criminal trial came to be seen as an opportunity for the defendant's lawyer to test the prosecution case. The privilege against self-incrimination entered common law procedure (together with the beyond-reasonabledoubt standard of proof and the exclusionary apparatus of the modern law of criminal evidence) as part of this profound reordering of the trial. It was the capture of the criminal trial by lawyers for prosecution and defense that made it possible for the criminal defendant to decline to be a witness against himself.

As a convenient shorthand, and with apology for the inelegance of the terms, I shall contrast these two conceptions of the criminal trial as the older "accused speaks" theory and the newer "testing the prosecution" theory. So long as the older view of the purpose of the trial held sway, the defendant's refusal to respond to the incriminating evidence against him would have been suicidal. Without counsel, the testimonial and defensive functions were inextricably merged, and refusing to speak would have amounted to a forfeiture of all defense. The sources show that criminal defendants did not in fact claim any such self-destructive right. Until the later eighteenth century, for almost all criminal defendants, defending meant responding in person to the details of the accusation. Only with the ascendance of defense counsel did the "testing the prosecution" trial develop, and only then did it become possible to speak of a privilege against self-incrimination in common law criminal procedure.

Part I of this essay discusses the several attributes of early modern criminal procedure that combined, until the end of the eighteenth century, to prevent the development of the common law privilege. Part II explains how prior scholarship went astray in locating the common law privilege against self-incrimination in the wrong events and in the wrong century.

\section{The "Accused SPEAKs" TRIAL}

In order for a privilege against self-incrimination to function, the criminal defendant must be in a position to defend by proxy. If the defendant is to have a right to remain silent that is of any value, he 
must be able to leave the conduct of his defense to others. By constricting the use of defense witnesses and defense counsel, common law criminal procedure in the early modern period effectively closed off most avenues of defense-by-proxy. Undergirding the criminal procedure of the early modern trial at common law was a set of rules and practices whose purpose and effect were to oblige the accused to respond to the charges against him.

The "accused speaks" trial was already thoroughly entrenched in the 1550s and 1560s, when the historical sources first allow us to see how English criminal trials were conducted. In the treason trial of Sir Nicholas Throckmorton (1554), the plucky defendant complains of many aspects of the procedure to which he is subjected, but not about the incessant questioning from the bench and from prosecuting counsel. ${ }^{4}$ Sir Thomas Smith, in the notable Elizabethan tract, De Republica Anglorum, ${ }^{5}$ describes a hypothetical criminal trial held at provincial assizes about the year 1565 . Smith depicts the defendant engaged in a confrontational dialogue with the victim and accusing witnesses, responding immediately to each new item of prosecution evidence. Functioning without the aid of counsel and speaking unsworn, Smith's criminal defendant replies insistently to the questioning and to the testimony of his accusers. After the victim of a robbery testifies to his version of the events, then "the thief will say no, and so they stand a while in altercation . ..." This famous image of the accused and accuser "in altercation" about the events exemplifies the "accused speaks" trial, the trial whose purpose was to provide the accused an opportunity to explain away the prosecution case.

\section{A. Denial of Defense Counsel}

The bedrock principle of criminal procedure that underlay the "accused speaks" trial was that a person accused of serious crime ${ }^{7}$ was forbidden to have defense counsel. Various justifications were put

4. "How say you, Throckmorton, did not you send Winter to Wyat into Kent, and did devise that the Tower of London should be taken ... ?" The Trial of Sir Nicholas Throckmorton, 1 Complete Collection of State Trials 869, 872 (1554) (T.B. Howell ed., London, T.C. Hansard 1816) [hereinafter STATE TRIALS]. "But how say you to this, that Wyat and you had conference together sundry times at Warner's house, and in other places?" Id. at 874.

5. Thomas Smith, De Republica ANglorum, bk. 2, ch. 23, at 114 (Mary Dewar ed., 1982) (1st ed. 1583, written circa 1565).

6. Id.

7. The prohibition on defense counsel was a rule applied to treason and felony. The rule did not extend to misdemeanor. The main rationale for exempting misdemeanor from the prohibition was that some of what was prosecuted as misdemeanor was regarded as essentially civil in character - for example, the question of whether a property owner was responsible for maintaining particular roadside ditches. See Michael Dalton, The Countrey Justice 51-55 
forth for this rule. ${ }^{8}$

\section{Court as Counsel}

It was dogma that the court was meant to serve as counsel for the prisoner. ${ }^{9}$ Alas, in many of the great political cases of the sixteenth and seventeenth centuries, the behavior of the bench scarcely bespoke fidelity to the interests of the defendant. For example, Bromley, the presiding judge in Throckmorton's trial, joins the prosecuting counsel, Stanford, in urging Throckmorton to confess the charges, assuring Throckmorton that "it will be best for you." 10 In John Lilburne's 1649 trial, the presiding judge, Keble, having heard the prosecution case mounted by the attorney general but not yet having heard Lilburne's defense, announces to the jury: "I hope the Jury hath seen the Evidence so plain and so fully, that it doth confirm them to do their duty, and to find the Prisoner guilty of what is charged upon him." 11 Most of us would hope that our defense counsel could do somewhat better by us.

The Tudor-Stuart bench had its own problems in this turbulent era. Until 1701, judges held office at the pleasure of the crown; ${ }^{12}$ the

(London 1619)†; see also J.M. BEATTIE, CRIME AND THE COURTS IN ENGLAND: $1660-1800$, at $339 \&$ n.62 (1986).

In the reform movement that ultimately led to the use of defense counsel in cases of serious crime, critics of the prohibition contrasted the liberty of defense that was allowed in civil litigation and in misdemeanor. "[W] hat Rule of Justice is there to warrant [the] Denial [of counsel], when in a Civil Case of a Halfpenny Value the Party may plead either by himself or Advocate[?]" Sir BARTHOlOMEW Shower, ReASONS FOR A NEW BILl OF RIGHTS 6 (London 1692). Blackstone wrote: "For upon what face of reason can that assistance [of counsel] be denied to save the life of a man, which yet is allowed him in prosecutions for every petty trespass?" 4 WILLIAM Blackstone, Commentaries on the Laws of ENGland 355 (4 vols.) (Oxford, Clarendon 1765-1769)†.

8. Some of the discussion that follows is outlined in John H. Langbein, The Criminal Trial Before the Lawyers, 45 U. CHI. L. REv. 263, 307-11 (1978).

9. "[T] he Court ought to be . . . of counsel for the prisoner, to see that nothing be urged against him contrary to law and right ...." EDw. COKE, THE THIRD PART OF THE INSTITUTES of the Laws of England: Concerning High Treason, and Other Pleas of the CROWN, AND CRIMINAL CAUSES 29 (London, M. Flesher 1644) (posthumous publication, written $1620 \mathrm{~s}-1630 \mathrm{~s})$.

10. Nicholas Throckmorton, 1 STATE Trials, supra note 4, at 877 . The same report discloses: "Then the Chief Justice Bromley remembered particularly all the Depositions and Evidences given against the prisoner, and either for want of good memory, or good will, the prisoner's Answers were in part not recited: whereupon the prisoner craved indifferency, and did help the Judge's old memory with his own recital." Id. at 897.

11. John Lilburne, 4 STATE Trials, supra note 4, at 1269, 1382 (1649). Lilburne's defense does not change Keble's mind. After hearing Lilburne, Keble tells the jury that "you will clearly find that never was the like treason hatched in England." Id. at 1402. The jury disagreed. See infra note 131 for further discussion of Lilburne's 1649 trial.

12. See Act of Settlement, 12 \& 13 Will. 3, ch. 2 \& 3 (1701). For background on the Act, see Barbara A. Black, Massachusetts and the Judges: Judicial Independence in Perspective, 3 LAW \& Hist. Rev. 101, 103.12 (1985). 
tradition of secure judicial independence lay in the future. Thus, remarked John Hawles in a famous tract published in 1689 after the overthrow of James II, the Stuart political trials had revealed that the judges "generally have betrayed their poor Client, to please, as they apprehended, their better Client, the King . . . ."13

The judges safeguarded the interests of the accused more responsibly in cases of nonpolitical crime. Because such trials go largely unnoticed in the State Trials ${ }^{14}$ and other law reports of the period, what we know of these cases of routine crime comes mostly from the problematic pamphlet accounts of Old Bailey trials and Surrey assize proceedings. ${ }^{15}$ The ordinary criminal case lacked prosecution counsel as well as defense counsel. Accordingly, it was the task of the trial judge to help the accuser establish the prosecution case ${ }^{16}$ as well as to be "counsel for the defendant" in the peculiar and restricted sense being described.

The defendant's supposed entitlement to have the trial judge serve as his defense counsel was limited to matters of law, not fact. "[T]he court ... are to see that you suffer nothing for your want of knowledge in matter of law," Chief Justice Hyde told a treason defendant in 1663, explaining the limits of the court's duty "to be of counsel with you."17 John Beattie captures the matter with great insight, observing that the idea that the court would be counsel for the defendant meant "that the judges would protect defendants against illegal procedure, faulty indictments, and the like. It did not mean that judges would help the

13. John Hawles, Remarks Upon the Tryals of Edward Fitzharris, Stephen Colledge, Count Coningsmark, THe Lord Russel, Collonel Sidney, Henry Cornish and Charles Bateman 22 (London, Jacob Tonson 1689), reprinted in TRYals of LD. WM. Russell \& Ye. Rye Plotters (n.p., n.d.). 67.

14. On the provenance and contents of the State Trials, see Langbein, supra note 8, at 264-

15. The Old Bailey Sessions Papers are discussed id. at 267-72; see also John H. Langbein, Shaping the Eighteenth-Century Criminal Trial: A View from the Ryder Sources, 50 U. CHI. L. REv. 1, 3-18 (1983). Regarding an equivalent series of pamphlet assize reports for the county of Surrey, see BEATTIE, supra note 7, at 23-25, 649-51 (discussing the Surrey pamphlets); see also id. at 99-106 (discussing murder trials reported there). The pamphlet reports originated as popular literature to entertain nonlawyers, and the accounts of the trials omit much of the detail that historians wish to know.

16. "[T] he common practice clearly was for the judge to take [the victim and any accusing witnesses] through their testimony line by line, acting as both examiner and cross-examiner, until he was satisfied that the fullest possible case had been presented." BEATTIE, supra note 7, at 342; see id. at 345 (commenting on "the judge's immense influence on the way the jury received the evidence and the impression it made on them," including his exercise of the power "to comment on the testimony as it was being given").

17. John Twyn, 6 STATE Trials, supra note 4, at 513, 516 (1663). Jermin, J. put the matter quite differently, telling Lilburne from the bench that "the court are of your counsel so far as to fact," but that if a matter of law arises, "you may, and ought to have other counsel assigned." John Lilburne, 4 STATE Trials, supra note 4, at 1297-98. 
accused to formulate a defense or act as their advocates."18 Indeed, the idea of the court as counsel "perfectly expresses the view that the defendant should not have counsel in the sense that we would mean."19 Consequently, "accused felons had to speak in their own defense and to respond to prosecution evidence as it was given, and as they heard it for the first time. If they did not or could not defend themselves, no one would do it for them."2o

The judges did intervene on occasion to help the defendant in the realm of fact, mainly by cross-examining a suspicious prosecution witness when the defendant appeared ineffectual. But these initiatives were episodic and unpredictable. "Judges were only occasionally moved to engage in vigorous cross-examinations .... For the most part they took the evidence as they found it .... They certainly did not prepare in detail for examination and cross-examination; they were not briefed."21 Thus, although the judges had no reason to persecute wrongfully accused persons, neither had the judges any particular incentive to be vigilant on behalf of defendants. In fact, the judges had a considerable incentive to conduct trials in a fashion that would not interfere with the orderly processing of their large criminal caseloads. ${ }^{22}$

\section{The Accused as a Testimonial Resource}

The classic justification ${ }^{23}$ for deliberately denying the defendant any assistance of counsel in matters of fact appears in the second vol-

18. John M. Beattie, Scales of Justice: Defense Counsel and the English Criminal Trial in the Eighteenth and Nineteenth Centuries, 9 LAw \& Hisr. REv. 221, 223 (1991).

19. Id. (emphasis added).

20. Id.

21. Id. at 233. As late as 1827, a prominent judge - Baron William Garrow, who had come to renown as an Old Bailey defense counsel in the $1780 \mathrm{~s}$ and $1790 \mathrm{~s}$, see id. at $236-47$ - explained to a grand jury that, although the judges were counsel for the defendants, " "they could not suggest the course of defence [that] prisoners ought to pursue.'" Id. at 254 (quoting Garrow).

22. For discussion of criminal caseloads and caseload pressures on the bench, see BEATTIE, supra note 7, at 376-78; Langbein, supra note 8, at 274-78; Langbein, supra note 15, at 115-23.

23. Sir Edward Coke tossed off a different rationale, a one liner about the standard of proof, which did not resonate in later discussions about denying defense counsel. He thought that "the testimonies and the proofs of the offense ought to be so clear and manifest, as there can be no defense of it." CoKE, supra note 9, at 29. (I owe this reference to Michael Macnair.) The notorious Chief Justice Scroggs resurrected this idea in one of the Popish Plot cases, explaining that the accused was not entitled to counsel because "the proof belongs to [the crown] to make out these intrigues of yours; therefore you need not have counsel, because the proof must be plain upon you, and then it will be in vain to deny the conclusion." Edward Coleman, 7 STATE TRIALS, supra note 4, at 1, 14 (1678), cited in 1 STEPHEN, supra note 2, at 382 . The idea that affirmative "full proof" precludes defensive disproof has a long history in continental procedure. See, e.g., A. Esmein, Histoire de la Procedure Criminelle en France 146-47 (Paris, L. Larose et Forcel 1882). 
ume of Serjeant William Hawkins' hugely influential treatise, Pleas of the Crown, ${ }^{24}$ first published in 1721.

The defendant needs no counsel, wrote Hawkins, because, if the defendant is innocent, he will be as effective as any lawyer. "[E]very one of Common Understanding may as properly speak to a Matter of Fact, as if he were the best Lawyer ...."25 If the defendant is guilty, however, "the very Speech, Gesture and Countenance, and Manner of Defense of those who are Guilty, when they speak for themselves, may often help to disclose the Truth, which probably would not so well be discovered from the artificial Defense of others speaking for them."26 The words speak, speech, and speaking appear four times in this short passage, epitomizing in contemporary narrative the image of the "accused speaks" trial.

Hawkins' insistence that the innocent criminal defendant enjoyed a comparative advantage in defending himself at trial is preposterous. Beattie describes the ineptitude of pathetic prisoners attempting to conduct their own trials:

[M]en not used to speaking in public who suddenly found themselves thrust into the limelight before an audience in an unfamiliar setting and who were for the most part dirty, underfed, and surely often ill did not usually cross-examine vigorously or challenge the evidence presented against them. Not all prisoners were unprepared or tonguetied in court. But the evidence of the printed reports of assize trials in Surrey suggests that it was the exceptional prisoner who asked probing questions or who spoke effectively to the jury on his own behalf. ${ }^{27}$

As I have written elsewhere, "Hawkins' message is that it is desirable for the accused to speak, either to clear himself or to hang himself."28 Allowing counsel to meddle with the fact-adducing process would impair the basic purpose of the trial: to hear the defendant speak, not to listen to "the artificial Defense of others." 29 Hawkins was warning that the intermediation of counsel would threaten a fundamental premise of the criminal trial of his day - that the defendant should be routinely available as a testimonial ${ }^{30}$ resource.

24. 2 William hawkins, a Treatise of the Pleas of the Crown (London 1721). Volume 1 appeared in 1716. The book underwent seven editions through 1795 and an eighth in 1824. 2 SWEeT \& MAXWell's Complete LAW Book CATAlogue 116 (1931).

25. 2 HawkINS, supra note 24 , ch. $39, \S 2$.

26. Id. .

27. BEATTIE, supra note 7, at 350-51 (footnote omitted).

28. Langbein, supra note 15 , at 124.

29. See supra text accompanying note 26.

30. By "testimonial," I mean that the defendant spoke to the merits, even though, until the Criminal Evidence Act, 1898, 61 \& 62 Vict., ch. 36, the defendant was forbidden from speaking on oath. Regarding the background of the English legislation of 1898 and corresponding American enactments, see Graham Parker, The Prisoner in the Box - The Making of the Criminal 
The purpose of the rule denying defense counsel was, therefore, diametrically opposed to the purpose of the privilege against selfincrimination. I touch here upon a deeper truth: The privilege against self-incrimination is the creature of defense counsel. The privilege could not emerge so long as the court required the defendant to conduct his own defense. In the "accused speaks" trial of the early modern period, the testimonial function was merged with the defensive function. The right to remain silent when no one else can speak for you is simply the right to slit your throat, and it is hardly a mystery that defendants did not hasten to avail themselves of such a privilege.

\section{Restricting the Role of Counsel}

Even after the judges relaxed the prohibition upon defense counsel in the middle of the eighteenth century, ${ }^{31}$ they limited counsel's role in order to continue to pressure the defendant to speak at his trial. The judges permitted defense counsel to examine and cross-examine witnesses, but they did not allow counsel to "address the jury" until legislation authorized that step in 1836.32

In 1777 a trial judge explained the practice of the day to a defendant at the Old Bailey: "Your counsel are not at liberty to state any matter of fact; they are permitted to examine your witnesses; and they are here to speak to any matters of law that may arise; but if your defense arises out of a matter of fact, you must yourself state it to me and the jury." 33 In an Old Bailey case two decades earlier, when the trial judge called upon the defendant to make his case at the conclusion of the prosecution evidence, the defendant is recorded as saying, "My counsel will speak for me." Counsel at once corrects him: "I can't speak that for you, you must speak for yourself." 34

Evidence Act, 1898, in LAW and Social Change in British History: Papers Presented TO THE BRISTOL LeGAl History CONFERENCE 156 (J.A. Guy \& H.G. Beale eds., 1984); Joel N. Bodansky, The Abolition of the Party-Witness Disqualification: An Historical Survey, $70 \mathrm{KY}$. L.J. 91, 105-29 (1981-1982).

31. See infra text accompanying notes 86-90.

32. 6 \& 7 Will. 4, ch. 114 (1836) ("An Act for enabling Persons indicted of Felony to make their Defense by Counsel or Attorney").

33. Russen, OBSP (Oct. 1777)†, at 374, cited in Stephan Landsman, The Rise of the Contentious Spirit: Adversary Procedure in Eighteenth Century England, 75 CORNELl L. REv. 497, 534 n.183 (1990).

34. Murdock, OBSP (Oct. 1755, \#377), at 333, 335†, extracted in Langbein, supra note 15, at 130. For another example, see id. at 130 n.516. Beattie reports an instance from Surrey assizes in 1752, in which the accused tries to leave his defense to his counsel, who declines it. The judge then explains: "Your counsel knows his duty very well, they may indeed speak for you in any matter of law that may arise on your trial, but cannot as to matter of fact, for you must manage your defense in the best manner you can yourself." BEATTIE, supra note 7, at 360 (citing the case of Derby, Surrey Assize Proceedings (Lent 1752), at 2-11). 
Thus, even with defense counsel on the scene, the English legal system of the mideighteenth century was telling the criminal defendant that "you must speak for yourself." This aspiration to capture the defendant as a testimonial resource is perfectly understandable. He is, after all, the most efficient possible witness. Guilty or innocent, he has been close enough to the events to get prosecuted for the offense. Modern continental systems continue to emphasize the advantages of treating the accused as the central testimonial resource. ${ }^{35}$ But this is not the conception of criminal procedure that we associate with the Anglo-American privilege against self-incrimination. It seems plainly contradictory to assert that there was a right to remain silent in the eighteenth century when eighteenth-century courts were routinely explaining, even to defendants who were represented by counsel, that "you must speak for yourself."

\section{B. Restrictions on Defense Witnesses}

The goal of pressuring the accused to speak in his own defense was achieved not only by denying or restricting counsel, but also by impeding defense witnesses. As with the limitations upon counsel, these obstacles to witnesses obliged the defendant to do his defending by himself - that is, by speaking at his trial.

Throughout the seventeenth century the defendant had no right to subpoena unwilling witnesses. Indeed, in the sixteenth century there were prominent occasions on which trial courts refused to hear defense witnesses who were present in court and willing to testify. ${ }^{36}$ When defense witnesses were received, they were forbidden to testify upon oath, ${ }^{37}$ although accusing witnesses were routinely sworn. The defendant always spoke unsworn - he was forbidden the right to testify upon oath until $1898 .{ }^{38}$

35. See, e.g., Mirjan R. Damaska, The Faces of Justice and State Authority: A Comparative Approach to the Legal Process 128 (1986); Mirjan Damaska, Evidentiary Barriers to Conviction and Two Models of Criminal Procedure: A Comparative Study, 121 U. PA. L. REv. 506, 526-30 (1973).

36. Nicholas Throckmorton, 1 STATE TRIALS, supra note 4, at 884-85; John Udall, 1 STATE TrIALS, supra note 4, at 1271, 1281, 1304 (1590). These cases are discussed in Peter Westen, The Compulsory Process Clause, 73 Mich. L. Rev. 71, 83 n.40 (1974); JAMes B. ThaYer, A PreLIMINARY TREATISE ON EVIDENCE AT THE COMmoN LAW 158-59 (Boston, Little, Brown 1898).

37. See supra note 30.

38. Coke, writing in the 1620 s or 1630 s, criticized the rule:

And to say the truth, we never read in any Act of Parliament, ancient Author, Book case, or Record, that in Criminal cases the party accused should not have witnesses sworn for him; and therefore there is not so much as scintilla juris against it. ... And when the fault is denied, truth cannot appear without witnesses.

COKE, supra note 9 , at 79.

Coke pointed with approval to the act that provides for the trial in England of felonies com- 
I suspect that the authorities came to view these limitations on the use of defense witnesses as counterproductive, in the sense that the manifest asymmetry of facilitating prosecution witnesses while denying or hampering defense witnesses offended trial jurors. ${ }^{39}$ Perhaps that is why John Lilburne, who was straining to provoke the sympathy of the trial jurors in his 1649 trial, insisted on the right to compulsory process that he knew was not allowed him. According to the State Trials report, Lilburne asks for "subpoenas" for witnesses, because some "are parliament men, and some of them officers of the army, and they will not come in without compulsion."40

The Treason Act of 1696 granted compulsory process and allowed defense witnesses to be sworn, but only for treason cases. ${ }^{41}$ Legislation of 1702 allowed defense witnesses to be sworn in routine felony trials. ${ }^{42}$ The courts construed that legislation as impliedly authorizing compulsory process as well. ${ }^{43}$

Thus, throughout the seventeenth century, the period during which the standard historical account supposes the development of the privilege against self-incrimination at common law, the rules of trial hampered the use of the alternative means of proof - those defense witnesses who would have been needed if the accused were to have an effective right to remain silent.

\section{The Standard of Proof Inchoate}

McCormick pointed out decades ago that the beyond-reasonabledoubt standard of proof was not precisely articulated in English law until the last decade of the eighteenth century. ${ }^{44}$ Barbara Shapiro has

mitted across the Scottish border and allows defense witnesses to be examined on oath "for the better information of the consciences of the Jury and Justice." 4 Jam. 1, ch. 1, $\S 6$ (1606). The act is discussed in Michael R.T. Macnair, The Law of Proof in Early Modern England 238-40 (1991) (unpublished Ph.D. dissertation, Oxford University, drawing on THE PARLIAMENTARY DIARY OF ROBERT BOWYER: 1606-07, at 300-63 (David H. Wilson ed., 1931)).

39. Throckmorton, who was acquitted, seems, if the report can be credited, to have been trying to call the jury's attention to the unfaimess of the court's excluding his witness. When the court refuses the witness, John Fitzwilliams ("Go you ways, Fitzwilliams, the court hath nothing to do with you; peradventure you would not be so ready in a good cause," Nicholas Throckmorton, I STATE TRIALS, supra note 4, at 885), Throckmorton turns to the jury and says, "Since this gentleman's Declaration may not be admitted, I trust you of the Jury can perceive, it was not for any thing he had to say against me; but contrarywise, that it was feared he would speak for me." Id. On the defects of the State Trials in general and the Throckmorton report in particular, see G. Kitson ClaRK, The Critical Historian 92-114 (1967).

40. John Lilburne, 4 STATE TRIALS, supra note 4, at 1312.

41. Treason Act of 1696,7 Will. 3 , ch. $3, \S \S 1$, 7; see infra text accompanying notes 84-92 (discussing the Act).

42. 1 Anne, stat. 2 , ch. $9, \S 3$ (1702) (part of an omnibus criminal law revision act).

43. See the authorities collected in Westen, supra note 36 , at 90 n.73.

44. See Charles T. MCCoRMICK, HANDBOoK of THE LAW OF Evidence $\S 321$, at $681-82$ 
collected a good deal of authority showing that there were strong intimations throughout the eighteenth century and earlier that the trier should resolve doubts in favor of the criminal defendant. ${ }^{45}$ Still, for so long as the beyond-reasonable-doubt standard lacked crisp formulation, the imprecision pressured the defendant to speak. As Beattie observes of the eighteenth-century sources,

if any assumption was made in court about the prisoner himself, it was not that he was innocent until the case against him was proved beyond a reasonable doubt, but that if he were innocent he ought to be able to demonstrate it for the jury by the quality and character of his reply to the prosecutor's evidence. That put emphasis on the prisoner's active role. He was very much in the position of having to prove that the prosecutor was mistaken.

... When the evidence had been given for the prosecution, the judge turned to the prisoner and said in effect: "You have heard the evidence; what do you have to say for yourself?" The implications of the judge's question were perfectly clear. When one [defendant on trial for larceny in Surrey in 1739] responded simply "I am no thief" and the judge told him "You must prove that," he was stating plainly the situation that every prisoner found himself in. ${ }^{46}$

Thus, the defendant, who already lacked counsel to probe the prosecution case, also lacked the protection of the modern judicial instruction on the standard of proof that encourages jurors to probe the prosecution case. The defendant had only one practical means of defense responding in his own words to the evidence and the charges against him.

\section{Hindering Defensive Preparation}

Most defendants accused of serious crime were jailed pending trial, and the conditions in the jails were appalling. ${ }^{47}$ Pretrial confinement interacted with the rest of the procedure to disadvantage the defendant, effectively preventing the defendant from locating witnesses and

\& n.3 (1st ed. 1954). The beyond-reasonable-doubt formula appears to have been employed in Massachusetts in the 1770s. See Anthony A. Morano, A Reexamination of the Development of the Reasonable Doubt Rule, 55 B.U. L. REV. 507, 516-19 (1975).

45. Barbara J. Shapiro, "Beyond Reasonable DoubT" and "Probable Cause": Historical Perspectives on the ANglo-American LAW of Evidence 1.41 (1991).

46. BEATTIE, supra note 7, at 341,349 (footnote omitted).

47. On the wretched jail conditions in the eighteenth century, see id. at 288-309. "Gaols in the sixteenth and seventeenth centuries were notoriously decrepit - unfit to "keep the prisoners free from wind and weather', as an Essex grand jury put it - and almost always overcrowded and insanitary." JAMES S. CockBuRN, A HistoRY OF ENGlish Assizes: 1558-1714, at 107 (1972) (footnote omitted). For data on "prison mortality" in the suburban London jails, see James S. Cockburn, InTroduction, Calendar of Assize Records: Home Circuit INDICTMENTS ELIZABETH I AND JAMES I, at 36-39 (1985) [hereinafter COCKBURN, CALENDAR] (noting there were 1291 deaths in the Home Circuit jails between 1559 and 1625). 


\section{developing his defense. ${ }^{48}$}

The law also forbade the defendant from having a copy of the indictment specifying the charges against him, not only in advance of trial, but even at trial. Instead, the court clerk summarized the indictment to the defendant upon his arraignment. The Treason Act of 1696 abrogated the rule against allowing the accused access to the text of the indictment, but only for cases of treason. ${ }^{49}$ For ordinary felony cases, the rule endured throughout the eighteenth century, ${ }^{50}$ and it impaired the defendant's ability to prepare his defense with precision. 51

Thus, the defendant was not only locked up, denied the assistance of counsel in preparing and presenting his defense, and restricted in obtaining defense witnesses, he was also given no precise statement of the charges against him until he stood before the court at the moment of his trial. The total drift of these measures was greatly to restrict defensive opportunity of any sort other than responding personally at trial to the incriminating evidence. This aspect of the procedure was not disturbing to contemporaries. Responding in person is just what Serjeant Hawkins' treatise insists the defendant ought to do, and just what the trial sources depict the defendant doing. The logic of the early modern criminal trial was to pressure the accused into serving as

48. Speaking of the great state trials of the century before the Interregnum, Stephen wrote:

The part of the early criminal procedure which seems to me to have borne most hardly on the accused was the secrecy of the preliminary investigation, and the fact that practically the accused person was prevented from preparing for his defense and from calling witnesses. ... The one great essential condition of a fair trial is that the accused person should know what is alleged against him, and have a full opportunity of answering either by his own explanations or by calling witnesses, and for this it is necessary that he should have a proper time between the trial and the preparation of the evidence for the prosecution. STEPHEN, supra note 2, at 356-57.

49. $7 \& 8$ Will. 3 , ch. $3, \S \S 1,9$. The ostensible ground for this astonishing rule was to prevent the defendant from making assignments of error based on faulty Latin or comparable technicalities. When the Treason Act of 1696 abrogated the rule against granting the accused a copy of the indictment (for treason only), it imposed a quid pro quo: It precluded the defense from making assignments of error based upon indictment drafting defects unless the defense moved to quash the indictment in the trial court before the taking of any evidence. $7 \& 8$ Will. 3 , ch. $3, \S \S 1,9$.

50. See, eg., 2 Hawkins, supra note 24, at 402 . For discussion of the practice from 1664 into the early nineteenth century, see Douglas Hay, Prosecution and Power: Malicious Prosecution in the English Courts: 1750-1850, in Policing aNd Prosecution IN BRITAIN 1750-1850, at 343, 352 (Douglas Hay \& Francis Snyder eds., 1989).

51. Another practice that the Treason Act of 1696 eliminated, but only for the case of treason, was nondisclosure of the venire, the list of prospective jurors, a step that would facilitate the exercise of the defendant's challenge rights. $7 \& 8$ Will. 3, ch. $3, \S 7$. In cases of ordinary felony there was virtually no exercise of challenge rights. See Langbein, supra note 8, at 275-76; see also BEATTIE, supra note 7 , at 340 . Without counsel and the other aids in preparing one's defense, it is not surprising that nominal challenge rights were of little use. I suspect that the exercise of challenge rights by the ordinary felony defendant was regarded as an affront to the challenged jurors, who were commonly the social superiors of the accused, and that the defendant understood that he ought not to risk offending the remaining jurors by striking some of their peers. 
a testimonial resource. It is difficult to imagine that a system so preoccupied with obliging the accused to reply at trial could have been simultaneously intent upon constructing the counterprinciple that is embodied in the modern privilege against self-incrimination.

\section{E. The "Accused Speaks" Theory in Pretrial Procedure}

A criminal trial is an occasion for the consideration of evidence that has been previously collected. A truism of the study of criminal procedure is that the connection between pretrial and trial is intimate. We cannot understand the trial procedure of a legal system without knowing something about how the pretrial process collects evidence for trial. Likewise, to understand the pretrial we need to know how the agencies of trial will subsequently employ the materials that are being gathered in the pretrial.

The Anglo-American tradition tends to be too trial-centered, perhaps because of the drama of the criminal jury trial, and surely because of the importance that trial has had in landmark political cases. Yet, even in the Anglo-American systems, the everyday reality is that pretrial is vastly more important than trial. The evidence gathered determines many more outcomes than how it is subsequently presented. The trial is mostly a pageant that confirms the results of the pretrial investigation, and this truth is among the factors that explain why, when our criminal procedural system crumbled in the twentieth century under caseload pressures, our response was to dispense with trial altogether, transforming the pretrial process into our nontrial plea bargaining system..$^{52}$

The pretrial system that reigned in the second half of the seventeenth century - when, according to one historical writer, Leonard Levy, the privilege against self-incrimination "prevailed supreme" 53 in the common law criminal trial - was antithetical to any such privilege. By the midseventeenth century there had been in place for at least a century a system of pretrial inquiry that was devoted to pressuring the accused to incriminate himself. The Marian Committal Statute of $1555,{ }^{54}$ whose origins and operation I have discussed extensively elsewhere, ${ }^{55}$ required that a magistrate, called the justice of the peace (JP), should conduct a pretrial examination promptly after the

52. See generally Albert W. Alschuler, Plea Bargaining and Its History, 79 CoLuM. L. Rev. 1 (1979).

53. Leonard W. Levy, ORigins of the Fifth Amendment: The Right Against SELF-INCRIMINATION 325 (1968).

54. 2 \& 3 Phil. \& M., ch. 10, § 2 (1555).

55. John H. Langbein, Prosecuting Crime in the Renaissance 5-125 (1974). 
defendant had been apprehended. The JP was customarily a local gentleman active in civic affairs, not a career officer of the state. ${ }^{56}$ The Marian statute required the JP to transcribe anything that the defendant said that was "material to prove the felony."57 The statute directed the JP to transmit this document to the trial court, where it could be used in evidence against the accused.58 The Marian statute also required the examining JP to bind over the victim and other accusing witnesses to attend the trial and testify against the accused. 59 The emphasis on testimony against the accused was deliberate. The Marian JP was not the Continental juge d'instruction, not, that is, a professional judicial officer meant to gather evidence impartially. The Marian system was designed to collect only prosecution evidence. ${ }^{60}$ In crimes of state, the Privy Council and the law officers of the crown conducted comparable pretrial investigations. ${ }^{61}$

In a prominent article published in 1949, the evidence scholar Edmund Morgan remarked on the tension between the Marian pretrial procedure and the supposed privilege against self-incrimination in the early modern period:

56. Langbein, supra note 15, at 56-57. See generally JOHN P. DAwsON, A History of LAY

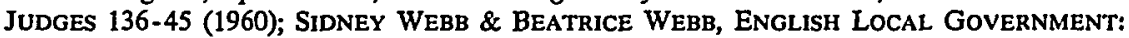
THE PARISH AND THE COUNTY 294-304, 319-446 (1906)†; Langbein, supra note 15, at 56-57.

57. 2 \& 3 Phil. \& M., ch. 10, § 2 (1555).

58. Sir Thomas Smith describes the Marian pretrial system circa 1565 , indicating that the JP's written summary of the pretrial examination was routinely read in court at the criminal trial. SMrTH, supra note 5 , at 109,113 . A generally reliable manual of assize procedure dating from the Restoration period says that the JPs routinely surrendered their pretrial examination documents to the clerk of assizes, who studied each, "and if it be Evidence for the King, [the clerk] readeth it to the Jury." T.W., THE CLERK OF AssIzE 14 (London 1660)†, quoted in Langbein, supra note 15 , at $82 \&$ n.315. See $i d$. for a discussion of this and other editions of the manual.

By the mideighteenth century, the pretrial examinations were not being read at trial routinely, partly as a consequence of a "best evidence" notion that preferred the oral evidence of the victim and the other accusing witnesses, whom the Marian statute required the JP to bind over to testify at trial. The pretrial examinations continued to be available at trial for impeachment and for exceptional circumstances, such as the death of the victim or witness. In the early nineteenth century, Mac Nally was still emphasizing that "[t]he confession of the defendant himself, taken upon an examination, in writing, before justices of the peace, in pursuance of the statutes of Philip and Mary . . . is legal evidence against the party confessing." 1 LEONARD MAC NALLY, The Rules of Evidence on Pleas of the Crown *37 (Philadelphia, Byrne 1811) (1st ed. 1802)†.

Regarding the strictures against allowing the accused's pretrial statement to be taken on oath, see infra note 142.

59. 2 \& 3 Phil. \& M., ch. 10, 2 (1555).

60. Barlow's JP manual patiently explains that, while the examining JP ought not to suppress evidence favorable to the accused when such evidence is part of the statement of a prosecution witness, the JP ought not to "examine Witnesses that expressly come to prove the Offender's Innocence." Theodore Barlow, The Justice of Peace: A Treatise Containing the POWER AND DUty OF That Magistrate 190 (London, Lintot 1745).

61. Pretrial depositions were used extensively at the subsequent trials - for example, the notorious early instance in Nicholas Throckmorton, 1 STATE TRIALS, supra note 4, at 869. 
There was no thought of advising the accused that he need not answer or warning him that what he said might be used against him. The justice [who had examined the defendant in the pretrial] was often the chief witness at the trial of the accused and either used his record of the examination as the basis for his answers or read the record in evidence for the prosecution. 62

Not until Sir John Jervis' Act of $1848^{63}$ — that is, well into the age of modern lawyer-dominated criminal procedure - was provision made to advise the accused that he might decline to answer questions put to him in the pretrial inquiry and to caution him $^{64}$ that his answers to pretrial interrogation might be used as evidence against him at trial. ${ }^{65}$ Until then, the accused was "expected to answer" the inquiries of the examining magistrate, "and, indeed, any refusal to answer, whether of his own initiative or on advice of another, was reported and stated by the magistrate in his testimony at the trial." 66

Thus, the pretrial procedure of the sixteenth, seventeenth, and eighteenth centuries was designed to induce the accused to bear witness against himself promptly. Having impaled himself at pretrial, the criminal defendant would find that any supposed privilege against selfincrimination available at trial was worth little. If he declined to testify at trial, or attempted to recant upon his pretrial statement, the pretrial statement would be invoked against him at trial. Then as now, pretrial dominated trial.

This systematic extraction of self-incriminatory pretrial statements bears upon the question of whether early modern English criminal procedure meant to recognize a privilege against self-incrimination. It seems odd to assert, as Levy does, that the privilege "prevailed supreme" 67 at trial when the pretrial procedure was so resolutely organized to render any such trial privilege ineffectual. Remarkably, Levy was quite aware of the character of the Marian pretrial process. Levy's passage reads in full text: "By the early eighteenth century, the [privilege against self-incrimination] prevailed supreme in all proceed-

62. E.M. Morgan, The Privilege Against Self-Incrimination, 34 MINN. L. REv. 1, 14 \& n.57 (1949) (citing cases from the State Trials occurring in 1664 and 1682).

63. 11 \& 12 Vict., ch. 42. See generally David Freestone \& J.C. Richardson, The Making of English Criminal Law: Sir John Jervis and His Acts, 1980 CRIM. L. REV. 5.

64. Mac Nally reports Irish authority from as late as 1799 that there was no duty to warn. Chamberlain, J., an Irish King's Bench judge, sitting on assize "admitted in evidence, on an indictment for felony, the confession of the prisoner, taken by a justice of the peace, in an examination in writing, though it appeared, on the justice's admission, that he had not warned the prisoner of the legal consequences of his making such confession." MAC NALLY, supra note 58, at $* 38$.

65. See Morgan, supra note 62 , at 14.

66. Id. at 18.

67. LEVY, supra note 53, at 325. 
ings with one vital exception, the preliminary examination of the suspect. In the initial pre-trial stages of a case, inquisitorial tactics were routine."68 "For all practical purposes," Levy concludes, "the right against self-incrimination scarcely existed in the pre-trial stages of a criminal proceeding." 69 This is an important admission. Levy requires us to believe that the seventeenth-century common law courts and their supporting political authorities created a self-evidently schizophrenic criminal procedure - that they enshrined a privilege against self-incrimination at trial while busily gutting it in the pretrial.

\section{F. Trial as a Sentencing Proceeding}

The sentencing practices of the later seventeenth and eighteenth centuries were a powerful source of pressure on the defendant to speak at his trial. Our modern expectation is that sentencing occurs in the postverdict phase, after a separate trial has determined guilt. Further, even in jury-tried cases, we expect the judge alone to pass sentence. In former centuries, this division between trial and post-trial, and between jury and judge, was less distinct. The early modern trial jury exercised an important role in what is functionally the choice of sanction, by manipulating the verdict to select a charge that imported a greater or lesser penalty. A vestige of this power to mitigate the sentence survives in modern practice, when the jury convicts of a lesserincluded offense, or when it convicts on fewer than all the counts that are charged and proved.

The practice of selecting among convicted persons for the application of diminished sanctions ${ }^{70}$ became characteristic of the eighteenth century as alternatives to the death penalty emerged. If the jury convicted a defendant of burglary, the punishment was death; but if, on the same facts, the jury convicted him of mere grand larceny, the sanction of transportation pertained. ${ }^{71}$ Another example: The offense of picking pockets was capital if the jury valued the stolen goods at a shilling or more. If, however, the jury wished to rescue the convict from capital punishment and consign him to transportation, it could value the goods below the one-shilling threshold, for example, by finding the culprit guilty of picking the victim's pocket "to the value of ten pence."72

68. Id.

69. Id. (footnote omitted).

70. Precursors of this jury-operated system of mitigation can be traced back into the medieval common law. Thomas A. GrEen, Verdict According to CONSCIENCE 97-102 (1985).

71. This is a main theme of BEATTIE, supra note 7; see especially id. at 450-519.

72. Langbein, supra note 15 , at 52 . Another common exercise of jury sentencing power con- 
This practice of having juries "downcharge" or "downvalue" in order to mitigate the death penalty, immortalized in Blackstone's phrase as "pious perjury,"73 has been much studied in recent years. It is a main theme of John Beattie's great book, in which he uses the term partial verdict to describe these mitigating jury verdicts that convict the defendant in a fashion that begets a reduced criminal sanction. ${ }^{74}$ In a sample of London cases from the Old Bailey in the 1750s, I found that the juries returned partial verdicts in nearly a quarter of the cases. ${ }^{75}$ For a few offenses, like picking pockets, the juries all but invariably downvalued, expressing a social consensus that the capital sanction was virtually never appropriate. At the opposite end of the spectrum were a few property crimes, highway robbery being the prototype, that were regarded as so menacing that juries virtually never mitigated the capital sanction. ${ }^{76}$ Across the broad range of property crimes, however, jury discretion held sway. In deciding whether to return verdicts of mitigation, "juries distinguished, first, according to the seriousness of the offense, and second, according to the conduct and character of the accused." 77

\section{Informing the Jury's Discretion}

The jury's power to mitigate sanctions profoundly affected the purpose of the criminal trial for those many offenses in which the jury might return a partial verdict. Speaking of the London practice in the 1750s, I have elsewhere written:

Only a small fraction of eighteenth-century criminal trials were genuinely contested inquiries into guilt or innocence. In most cases the accused had been caught in the act or otherwise possessed no credible defense. To the extent that trial had a function in such cases beyond formalizing the inevitable conclusion of guilt, it was to decide the sanction. ${ }^{78}$

cerned the charge of grand larceny - that is, the theft of goods valued at a shilling or more but not alleged to be one of the aggravated forms of theft such as burglary or stealing from specially protected premises. In the eighteenth century, transportation was the prescribed penalty for grand larceny (a shilling and above), whereas for petty larceny (theft of goods worth less than a shilling) mere whipping was the usual sanction. Here, too, if the jury wished to impose the lesser sanction, it framed the verdict to downvalue the goods. Id. at 52-53.

73. 4 BlACKSTONE, supra note 7, at 239.

74. See BEATTIE, supra note 7, at 419-30; see also 1 LeON Radzinowicz, A History of ENGLISH CRIMINAL LAW AND ITS ADMINISTRATION FROM 1750, at 83-106, 138-64 (1948).

75. See Langbein, supra note 15, at 52. From a much larger sample of Surrey cases, including lesser crime as well as felony, Beattie found comparable partial verdict rates $(24.9 \%)$ in the period $1700-1739$, then a decline to $12.7 \%$ for the period $1740-1779$, and $7.5 \%$ for the years 1780-1802. BEATTIE, supra note 7, at 419 n.32.

76. See Langbein, supra note 15 , at 53.

77. Id.

78. Id. at 41. 
Because the main purpose of defending such a case was to present the jury with a sympathetic view of the crime and the offender that would encourage a verdict of mitigation, the criminal defendant labored under an enormous practical compulsion to speak in his own defense. Criminal procedure of this period effectively merged the guilt determining function and the sentencing function into a single proceeding, the trial. The procedure foreclosed the defendant from participating in what was functionally his sentencing hearing unless he spoke at trial about the circumstances of the offense and of his life and character. To be sure, character witnesses could and did carry some of this burden for the defendant in some cases; it was not impossible to remain silent and still obtain jury leniency. But it was a grave risk that few defendants had the stomach to undertake.

The partial verdict system abated slowly, toward the end of the eighteenth century and during the early decades of the nineteenth century. Our modern system of postverdict judicial sentencing arose in response to many factors. The movement to revise the substantive criminal law by consolidating and rationalizing the categories of offenses invited the grading of sentences according to severity. This movement was deeply connected to the transformation of criminal sanctions, as imprisonment became the routine punishment for cases of serious crime. The older sanctions, death and transportation, had lent themselves to jury manipulation, because they came as "either-or" choices. The new sanction of imprisonment for a term of years was all but infinitely divisible. It invited the concept of the sentencing range, which effectively transferred from the jury to the judge the power to tailor the sentence to the particular offender. But, throughout the eighteenth century, the jury-driven system of mitigation by means of the partial verdict placed an enormous premium on the defendant's willingness to talk to the jurors at trial.

\section{Informing the Judge's Postverdict Review}

The trial judges exercised a postverdict discretion to recommend clemency to the crown. ${ }^{79}$ In administering the pardon process, the judges depended upon information gleaned at trial for their view of the offender. A main reason that the judges discouraged ${ }^{80}$ guilty pleas in

79. For discussion of the judicially dominated pardon process as a routine aspect of criminal procedure in the eighteenth century, see BEATTIE, supra note 7, at 430-49; RADZINowICZ, supra note 74, at 107-37; Langbein, supra note 15, at 19-21; John H. Langbein, Albion's Fatal Flaws, 98 PAST \& PRESENT 96, 109-14 (1983).

80. This issue is discussed with examples in Langbein, supra note 8, at 278-79. See also BEATTIE, supra note 7, at 336-37 \& n.52, concluding: "Virtually every prisoner [in Beattie's Surrey sample for the years 1663-1802] charged with a felony insisted on taking his trial, with the 
seventeenth- and eighteenth-century criminal trials was the wish to learn about the offender at trial in the event that a convict sought clemency. A Surrey assize judge sitting in a case in 1751 explained that he hanged a man who had pleaded guilty because the guilty plea had shut the judge "out from all evidence and circumstances favorable and disfavorable which might have appeared."81 Thus, the clemency aspect of the sentencing process reinforced the tendency of the jury mitigation system, placing the criminal defendant under further pressure to speak at his trial.

\section{G. No Privilege Claimed in the "Accused Speaks" Trial}

We have observed a host of reasons for doubting that the privilege against self-incrimination was in force in the later seventeenth and

obvious support and encouragement of the court. There was no plea bargaining in felony cases in the eighteenth century."

The tradition of discouraging guilty pleas was already ripe for mention in Sir Matthew Hale's History of the Pleas of the Crown, written sometime before the author's death in 1676. Hale says that "it is usual for the court ... to advise the party to plead and put himself upon his trial, and not presently to record his confession ...." 2 MATtHew HALE, THE History of THE PLEAS OF THE CROWN 225 (S. Emlyn ed.) (London 1st ed. 1736) (first edition, posthumous publication). Cockburn has documented an outbreak of plea bargaining on the Home Circuit for a period of three decades beginning in 1587, CocKBURN, CALENDAR, supra note 47, at 65-70, 105, but the practice appears not to have endured into the age of Hale and Hawkins. See also Neil H. Cogan, Entering Judgment on a Plea of Nolo Contendere, 17 ARIZ. L. REV. 992, 999-1016 (1975) (tracing some use of nolo-type pleas in early modern practice).

So long as trial procedure remained informal and lawyer-free, an assize court or its London equivalent, the Old Bailey, conducted trials extremely rapidly, at the rate of a dozen or more felony jury trials per day. Sources treating criminal caseloads and the caseload pressures on the bench are cited supra in note 22. I report that "an average of twelve to twenty [felony] cases per sessions day went to jury trial" at the Old Bailey in the decades from 1678 onward. Langbein, supra note 8, at 277; see also id. at 274-78. Beattie reckons jury trial caseloads of about 15 felony cases per day at Surrey assizes in the second half of the eighteenth century, for an average trial time of about half an hour per case. BEATTIE, supra note 7, at 378. Hence, caseload pressures were not yet causing the courts to want to elicit guilty pleas. Rather, the courts repeatedly urged criminal defendants not to plead guilty.

81. Quoted in John M. Beattie, Crime and the Courts in Surrey: 1736-1753, in CRIME IN ENGLAND 155, 173 (J.S. Cockburn ed., 1977). See generally Beattie, supra note 18, at 232 (discussing "the importance of having the accused speak for themselves" and noting that "[i]t is this need for a trial - and a trial of a certain kind - that explains the extraordinary fact that judges did everything in their power in the eighteenth century to prevent the accused, especially those on capital charges, from pleading guilty"). What Beattie calls "a trial of a certain kind" is, I think, what I have been calling in this paper the "accused speaks" trial.

The movement toward encouraging guilty pleas that is so familiar to us today in both English and American practice was, in my view, primarily a response to the complexity and time demands of full-dress adversary jury trial. Little is known about the timing of this event. The ordinarily astute French observer, Cottu, who studied English practice in the post-Napoleonic period, says that it "often happens" that "the prisoner pleads guilty" because he is certain that the death penalty will be commuted; but that, even then, "the judge cautions him that the crime alleged is capital, and that it is his interest to defend himself; the clerk, the gaoler, almost all the counsel, even the prosecutor's persuade him to take the chance of an acquittal ..." M. CorTu, ON THE ADMINISTRATION OF CRIMINAI JUSTICE IN ENGLAND 73 (anon. trans., London, Rich ard Stevens 1822) (translating De l'Administration de la Justice Criminelle en Angleterre (Paris 1820)). 
eighteenth centuries, the period in which historical writers posit that the privilege "prevailed supreme" at common law. Denial of counsel and restrictions on defense witnesses and on defensive preparation left the typical defendant with little alternative but to conduct his own defense. The invasive Marian pretrial process, untouched by any supposed privilege against self-incrimination, stacked the deck with selfincriminating evidence for the trial. And a system of draconian criminal sanctions frequently operated to condition escape from the death penalty upon the defendant's contrite participation at trial.

When, therefore, we examine the surviving evidence of how trials actually transpired in this legal system, we cannot be surprised to find that criminal defendants actually claimed no privilege against selfincrimination. In a word, they sang. Fifteen years ago I pointed out that, in the pamphlet reports of London trials "from the 1670s through the mid-1730s [where my study lapsed] I have not noticed a single case in which an accused refused to speak on asserted grounds of privilege, or in which he makes the least allusion to a privilege against self-incrimination." 82 I have subsequently followed this set of pamphlet reports into the 1770 s without finding any articulated claim to the privilege.

Beattie, concentrating on Surrey sources for the years between 1660 and 1800 , makes a similar observation: "There was no thought that the prisoner had a right to remain silent on the grounds that he would otherwise be liable to incriminate himself. . .." Indeed, "the assumption was clear that if the case against him was false the prisoner ought to say so and suggest why, and that if he did not speak that could only be because he was unable to deny the truth of the evidence." $" 83$

\section{H. Defense Counsel, Adversary Procedure, and the Privilege}

My theme in this essay is that the privilege against self-incrimination is an artifact of the adversary system of criminal procedure. Only when the modern "testing the prosecution" theory of the criminal trial displaced the older "accused speaks" theory did the criminal defendant acquire an effective right to decline to speak to the charges against him. The historical bearer of the new criminal procedure was defense counsel, who crept into the ordinary criminal trial almost unnoticed, and who then worked a drastic procedural revolution with conse-

82. Langbein, supra note 8 , at 283 . But see the discussion infra in note 142 regarding sensitivity in the contemporary sources about not conducting pretrial examinations upon oath.

83. BEATTIE, supra note 7, at 348-49. 
quences that still reverberate through Anglo-American criminal justice.

\section{Allowing Defense Counsel}

The prohibition on defense counsel was first relaxed in the landmark Treason Act of 1696,84 the first comprehensive charter of defensive safeguard in the history of our criminal procedure. ${ }^{85}$ During the $1690 \mathrm{~s}$, it came to be understood that the treason trials conducted under the regime of the later Stuarts had been grievously unfair. Especially during the dozen years from the Popish Plot trials of the later 1670 s until the Revolution of 1689 , innocent persons of the politically significant classes had been convicted and had suffered traitors' deaths for want of the ability to defend effectively against baseless prosecutions.

Defensive safeguard was a novel topic for English criminal legislation. The preamble to the Treason Act of 1696 announced the proposition that persons accused of treason should be allowed "just and equal means for defense of their innocencies in such cases." 86 The Act provided a package of reforms directed at eliminating many of the procedural disadvantages that undergirded the "accused speaks" trial. The Act allowed the accused a copy of the indictment five days in advance of trial; it granted the right "to advise with counsel" upon the indictment; and it spelled out the right at trial to make "full defense, by counsel" 87 - meaning that defense counsel would be permitted not only to examine and to cross-examine, but also to sum up and to address the jury about the merits of the defendant's case. ${ }^{88}$ The Act granted the accused the right to have defense witnesses heard, the right to have them sworn, ${ }^{89}$ and the right to have them subpoenaed. ${ }^{90}$

The grant of defense counsel in the Treason Act of 1696 was care-

84. 7 \& 8 Will. 3 , ch. $3, \S 1$ (1696).

85. See generally Alexander H. Shapiro, Political Theory and the Growth of Defensive Safeguards in Criminal Procedure: The Origins of the Treason Trials Act of 1696, 11 LAW \& HIST. Rev. 215 (1993); see also James R. Phifer, Law, Politics, and Violence: The Treason Trials Act of 1696, 12 Albion 235 (1980); Samuel Rezneck, The Statute of 1696: A Pioneer Measure in the Reform of Judicial Procedure in England, 2 J. MOD. Hist. 5 (1930).

86. 7 \& 8 Will. $3, \mathrm{ch} .3, \S 1$.

87. $7 \& 8$ Will. $3, \mathrm{ch} .3, \S 1$.

88. This step, allowing counsel to address the jury, was not taken for ordinary felonies until the legislation of 1836. See supra text accompanying note 32 .

89. 7 \& 8 Will. 3, ch. $3, \S 1$ ("to make any proof ... by lawful witness or witnesses, who shall then be upon oath").

90. $7 \& 8$ Will. 3 , ch. $3, \S 7$ ("to compel their witnesses to appear for them at any such trial or trials, as is usually granted to compel witnesses to appear against them"). 
fully limited to treason trials, which occurred extremely rarely. 91 There was a sense that treason defendants were specially disadvantaged on account of the hostility of the bench. Because judges were subservient to the crown in prosecutions touching high politics, it was unrealistic to expect them to serve the supposed judicial role of counsel for the defendant. Further, the denial of defense counsel had a special one-sidedness in treason cases, for the crown was invariably represented by counsel. By contrast, in cases of ordinary felony, prosecution counsel appeared exceedingly rarely. The rationale for allowing defense counsel in the Treason Act of 1696 was, therefore, to even the scales. ${ }^{92}$

Defense counsel entered the ordinary criminal trial in the 1730s, not as a result of legislative change, but through the exercise of judicial discretion..$^{93}$ Something of the same "evening-up" rationale that lay behind the allowance of defense counsel in the Treason Act of 1696 seems to have accounted for the decision of the courts to admit defense counsel in cases of ordinary felony. There appears to have been a considerable increase in the use of prosecution counsel in the $1710 \mathrm{~s}$ and $1720 \mathrm{~s}, 94$ and "the resulting disparity may have influenced the judges to relax the [prohibition on defense counsel]."95 The use of defense counsel remained a relative trickle for another half century, until the 1780s. 96

\section{The Adversary Dynamic and the Reconstruction of the Criminal Trial}

During the second half of the eighteenth century and continuing into the nineteenth century, our criminal procedure underwent that epochal change from the "accused speaks" trial to the modern "testing

91. See Langbein, supra note 8, at 309-10 (discussing the reasons for restricting defense counsel to treason cases).

92. Sergeant Hawkins, defending the rule forbidding defense counsel to persons accused of routine felony, explained to his readers in 1721 that the Treason Act of 1696 allowed defense counsel in treason cases because "[e]xperience [had revealed] that Prisoners have been often under great Disadvantages from the Want of Counsel, in Prosecutions of High Treason against the King's Person, which are generally managed for the Crown with greater Skill and Zeal than ordinary Prosecutions." HAWKINS, supra note 24, at 402.

93. Langbein, supra note 8, at 311-13.

94. Suggested on thin evidence in $i d$. at 311-12; substantially amplified by BEATTIE, supra note 7 , at 352-56.

95. Langbein, supra note 8, at 313; see also BEATTIE, supra note 7, at 359.

96. The sources are not good enough to allow us to measure with precision how frequently defense counsel appeared in the eighteenth century. Beattie's cautious account points to the 1780s. See Beattie, supra note 18, at 226-30. His calculations reckon percentages of defense counsel at the Old Bailey as low as $2.1 \%$ in the 1770 s, increasing to $20.2 \%$ in 1786 , and to a high of $36.6 \%$ in 1795 . Id. at 227 tbl. 1; see also Landsman, supra note 33, at 607. 
the prosecution" trial. We have seen how relentlessly the earlier system of trial pressured the criminal defendant to speak. Within the space of a few decades, the expectation that the accused would defend himself disappeared. Defense counsel made possible that remarkable silencing of the accused that has ever since astonished European commentators. As early as 1820 an official French observer, Cottu, reported back to his government that in English criminal procedure prosecuting counsel was "forbidden to question the prisoner .... In England, the defendant acts no kind of part: his hat stuck on a pole might without inconvenience be his substitute at the trial."97

We do not yet have an adequate historical account of the stages by which this transformation occurred, and the historical sources are sufficiently impoverished that we may never recover the events in adequate detail. Nevertheless, the outline seems tolerably clear. Across these decades, defense counsel broke up the "accused speaks" trial. In these developments we find not only the beginnings of a new theory of the trial, but also the real origins of the privilege against selfincrimination.

The initial restrictions on the role of defense counsel at trial suggest that his primary responsibility in the eighteenth century was cross-examining prosecution witnesses. Especially in cases involving reward seekers and crown witnesses, those shady figures whom the embattled London authorities sometimes employed to compensate for the English reluctance to institute professional policing, ${ }^{98}$ vigorous cross-examination often proved decisive. ${ }^{99}$ Thus, as Beattie remarks, defense counsel "began to shift the focus of the defense in a fundamental way by casting doubt on the validity of the factual case being presented against the defendant, so that the prosecution came increasingly under the necessity of proving its assertions." 100 There were several strands to this development of the trial as the occasion for defense counsel to test the prosecution case.

First, the concept that we now identify as party production burdens came to be articulated. Prosecution and defense "cases" replaced the spontaneous "altercation" described by Sir Thomas Smith. Smith's defendant replied to each piece of prosecution evidence as it

97. CoTtu, supra note 81 , at 105.

98. See Langbein, supra note 15 , at 84-114.

99. See BEATTIE, supra note 7, at 361-62, 374-75; Beattie, supra note 18, at 233-35, 244.

100. BEATTIE, supra note 7 , at 375 . Beattie has drawn attention to the daunting reputation of William Garrow as an Old Bailey defense counsel in the 1780s and 1790s. "[T]he greater participation of lawyers in criminal trials in the 1780s led not merely to more defendants being represented by counsel, but to a more committed advocacy of their cases in the courtroom and a new emphasis on their rights." Beattie, supra note 18, at 238. 
was presented. When defense counsel came to prominence, the concept of prosecution and defense "cases" developed - that is, the idea that the prosecution had to present all its evidence, and be subject to the defense counsel's motion for directed verdict ${ }^{101}$ at the end of the prosecution case, before the defendant would present rebuttal evidence.

Second, towards the end of the eighteenth century the presumption of innocence - the beyond-reasonable-doubt standard of proof - was formulated. ${ }^{102}$ Coupled with the prosecutor's production burden, the beyond-reasonable-doubt standard encouraged defense counsel to silence the defendant and hence to insist that the prosecution case be built from other proofs.

Third, the law of criminal evidence formed in the later eighteenth and early nineteenth centuries. "In their objections against the admission of certain kinds of evidence, and most especially by [their conduct of] cross-examination, defense counsel sought to limit the case their clients would have to answer."103 With the increasing use of lawyers from the 1780 s came lawyer's literature, especially the nisi prius reports, upon which the evidence treatises of the early nineteenth century would draw for sources. ${ }^{104}$

Fourth, the growing use and effectiveness of defense counsel begot ever greater use of prosecuting counsel. The private associations for the prosecution of felons formed in great numbers from the $1770 \mathrm{~s}$ and $1780 \mathrm{~s}^{105}$ These complex organizations served a number of functions, but their central purpose was to defray the victim's costs of investigation and prosecution in certain classes of property offenses. ${ }^{106}$ There is evidence for thinking that the surge in the formation of these groups reflects in part the need to prepare prosecution cases better, in order to deal with the new hazards of aggressive defense counsel as the "testing the prosecution" trial came to prevail. ${ }^{107}$

Fifth, the judge declined in importance as counsel for prosecution

101. Noticed obliquely in CoTtu, supra note 81 , at $98-99$.

102. See supra text accompanying note 45 .

103. Beattie, supra note 18 , at 235.

104. See William Twining, The Rationalist Tradition of Evidence Scholarship, in RETHINKING EVIDENCE 32 (1990) (discussing the development of treatise writing on evidence law); John H. Wigmore, $A$ General Survey of the History of the Rules of Evidence, in 2 SELECT ESSAYS IN ANGLO-AMERICAN LEGAI HistoRy 691, 695-97 (Assn. of Am. Law Sch. ed., 1908) (emphasizing the role of nisi prius reporting).

105. See David Philips, Good Men to Associate and Bad Men to Conspire: Associations for the Prosecution of Felons in England, 1760-1860, in Policing AND Prosecution IN BRITAIN 17501850 , supra note 50 , at $113-70$.

106. See John H. Langbein, Book Review, 9 LAw \& Hist. REv. 398, 402 (1991).

107. See Langbein, supra note 15 , at 128-29. 
and defense took over the job of examining and cross-examining witnesses. Cottu, the French observer writing in 1820, thought that prosecution and defense counsel were typical in the practice of provincial assize courts, although not yet in London. ${ }^{108} \mathrm{He}$ found that "the judge . . . remains almost a stranger to what is going on," 109 contenting himself with taking notes and summarizing them for the jury at the end of the trial. ${ }^{110}$

Finally, changes in the practice of jury control in this period, highlighted by Fox's Libel Act of 1792,111 reflect the decline of judicial influence over the trial jury. Counsel's increasing control of the conduct of the trial was inconsistent with the older informal system of jury control that presupposed the casual intimacy of judge and jury. ${ }^{112}$

Defense counsel silenced the criminal defendant in the second half of the eighteenth century for reasons of strategic advantage, as the logic of adversary procedure unfolded. Counsel welcomed the opportunity to pour this new wine into an old vessel, the maxim nemo tenetur prodere seipsum, the centerpiece of the traditional account of the history of the privilege against self-incrimination that is the subject of Part II of this essay. By the time that Bentham began complaining about the privilege against self-incrimination in the first decades of the nineteenth century, ${ }^{113}$ adversary procedure had become the norm. ${ }^{114}$ Defense counsel made the privilege against self-incrimination possible. Defense counsel disentangled the defensive and the testimonial functions that previously had been merged in the hands of the defendant. By assuming the defensive function, and doing it within the structure of the adversary criminal trial, counsel largely suppressed the defendant's testimonial role. Defense counsel must have been delighted to ascribe this radical reconstruction of the criminal trial to a centuriesold maxim of soothing constitutional dignity.

\section{ReVisiting A TROUBLED HistoricAl SchOLARSHIP}

The history of the privilege against self-incrimination at common

108. CoTTU, supra note 81 , at 88 .

109. Id.

110. Id. at 88,90 .

111. 32 Geo. 3, ch. 60. The Act completed the immunization of jurors who determined to return verdicts of acquittal in defiance of the applicable law. Such verdicts occurred infrequently, mostly in political cases.

112. On the older patterns of jury control, see Langbein, supra note 8, at 284-300.

113. See A.D.E. Lewis, The Background to Bentham on Evidence, 2 UTILITAs 195, 203-16 (1990); A.D.E. Lewis, Bentham's View of the Right to Silence, 43 CuRrent Legal Probs. 135, 138 (1990).

114. See supra note 96. 
law has long been a murky topic. A main source of confusion is that the modern common law privilege came to be associated with a doctrinal tag, the maxim nemo tenetur prodere seipsum, that developed in earlier centuries for quite different purposes.

\section{A. Antecedents to the Common Law Privilege \\ 1. Medieval Roots in European Law}

The Anglo-American adversary system repackaged doctrinal baggage that started its journey in the medieval law of the Roman church. The maxim nemo tenetur prodere seipsum, liberally translated as "no one is obliged to accuse himself," helped clarify the line between two spheres of Christian obligation. The believer's duty of penitential confession did not entail instituting criminal proceedings against himself. He could confess sin to a priest without being obliged to confess punishable offenses to judges and prosecutors. ${ }^{115}$

In a very important article, Richard Helmholz has recently shown how prominently the nemo tenetur maxim appeared in the Continental sources of the later Middle Ages and the Renaissance. ${ }^{116} \mathrm{He}$ has established that the nemo tenetur maxim influenced practice in the English ecclesiastical courts long before anybody in England started complaining about Star Chamber or the Court of High Commission. ${ }^{117}$ Helmholz's work, which has been confirmed in important respects in an article by Michael Macnair, ${ }^{118}$ delivers a devastating refutation of Leonard Levy's effort to portray the privilege against selfincrimination as an English invention intended to protect the indigenous adversarial criminal procedure against incursions of European inquisitorial procedure. ${ }^{119}$ The concept that underlies the English privilege against self-incrimination originated within the European tradition, as a subprinciple of inquisitorial procedure, centuries before the integration of lawyers into the criminal trial made possible the development of the distinctive Anglo-American adversary system of criminal procedure in the later eighteenth century.

115. See R.H. Helmholz, Origins of the Privilege Against Self-Incrimination: The Role of the European Ius Commune, 65 N.Y.U. L. REV. 962, 982 (1990).

116. Id. at $967,970-72,975-87$.

117. Id. at $969-89$.

118. Michael R.T. Macnair, The Early Development of the Privilege Against Self-Incrimination, 10 OXFORD J. LEGAL STUD. 66 (1990). The Helmholz and Macnair papers were published substantially contemporaneously and do not take account of each other. Macnair's main theme is that the privilege "came into English law from the common family of European laws and particularly the canon law." Id. at 67.

119. The sources "stand directly at odds with Levy's depiction of civilian procedure as the implacable foe of the privilege and of English liberties. Indeed, the ius commune appears to be the very source of assertions of the privilege." Helmholz, supra note 115, at 974. 


\section{The Ex Officio Oath}

Chapter Two, as it were, of the history of the privilege against selfincrimination is the saga of how the Puritans seized upon this concept of immunity from self-accusation as part of their struggle against Anglican religious conformity. The Puritans were resisting the efforts of Elizabethan (1558-1603) and early Stuart (1603-1640s) authorities to impose Anglican forms of worship. The ecclesiastical courts and the prerogative courts of High Commission and Star Chamber conducted disciplinary proceedings of various sorts. These courts investigated by means of the so-called "ex officio oath" procedure. 120 When employing this procedure, the court instructed the accused at the outset of the inquiry that he should swear an oath to answer any questions that the court might subsequently put to him. A defendant who refused to take that oath could be imprisoned for contempt or subjected to other harsh sanctions. Because these defendants were typically guilty of the nonconformist religious practices for which they were being investigated, they resisted submitting to ex officio oath procedure.

Particularly towards the end of their contest with the ecclesiastical and prerogative courts in the 1630s, the Puritans placed considerable weight upon the nemo tenetur maxim, using it to stand for the claim that they ought not to be punished for failing to cooperate in ex officio oath proceedings. The Puritans sometimes succeeded in resisting ex officio oath procedure as it was applied in the ecclesiastical and prerogative courts by obtaining relief from the common law courts. The common law courts issued writs of prohibition against some of the ex officio oath proceedings, often out of concern to limit subject matter encroachments upon common law turf. ${ }^{121}$

When political and military reverses forced Charles I to summon Parliament in 1641, Parliament sided with the Puritans, abolished the courts of Star Chamber and High Commission, and forbade the eccle-

120. See generally Mary H. Maguire, Attack of the Common Lawyers on the Oath Ex Officio as Administered in the Ecclesiastical Courts in England, in ESSAYS IN HISTORY AND POLITICAL THEORY IN HONOR OF CHARLes Howard McIlwaIN 199 (Carl Wittke ed., 1936).

121. In an important work correcting another side of Leonard Levy's book, Charles Gray has explained why it is mistaken to see this intervention as reflecting any consistent notion of a privilege against self-incrimination. Charles M. Gray, Prohibitions and the Privilege Against Selfincrimination, in TUdoR RULE AND Revolution 345 (Delloyd J. Guth \& John W. McKenna eds., 1982). Reviewing the prohibition practice of the Elizabethan and Early Stuart period, Gray concludes that "[a]t the level of technical law . . . a general privilege cannot be asserted." Id. at 366-67. Although the common law courts imposed some restrictions, they "never said that jurisdictions using civil-canon procedure could not expose individuals to self-incrimination." Id. at 367. 
siastical courts from using ex officio oath procedure. ${ }^{122}$ These events, especially the fall of Star Chamber, remain among the most celebrated landmarks of English political and legal history. The idea that no one need accuse himself, whatever that meant, was part of this constitutional triumph. As Henry Friendly observed, the precocious development of this "procedural" protection against intrusive questioning reflected the primitive state of the substantive law concerning religious and political liberties. ${ }^{123}$ If the protections for nonconformist worship and for opposition political discourse that Americans now associate with the First Amendment had been more developed, Puritans and political mavericks would not have had to campaign as they did for procedural protections against self-incrimination in Star Chamber and High Commission. ${ }^{124}$

\section{B. Common Law Criminal Procedure}

The great question is how the common law courts came to internalize a privilege against self-incrimination. Why take a principle that had been developed to counteract the ex officio procedures of the ecclesiastical and prerogative courts and apply that principle to the radically different circumstances of common law criminal procedure?

The historical literature, powerfully shaped by our pioneering scholar, Wigmore, ${ }^{125}$ affords a long-familiar account of this develop-

122. 16 Car. 1, ch. 11 (1640) (revised at the Restoration as 13 Car. 2, ch. 12 (1661)).

123. See Henry J. Friendly, The Fifth Amendment Tomorrow: The Case for Constitutional Change, 37 U. CIN. L. REv. 671, 696-98 (1968).

124. Id.

125. 8 JOHN H. WIGMORE, EvidENCE IN TRIALS AT COMMON LAW $\$ 2250$, at 267 (John T. McNaughton rev. ed. 1961). For convenience, I cite the 1961 edition of Wigmore's Volume 8, the so-called McNaughton revision, which is the currently available edition. As McNaughton explains, Wigmore's account of the history of the privilege against self-incrimination originated in two articles, John H. Wigmore, Nemo Tenetur Seipsum Prodere, 5 HARV. L. REv. 71 (1891), and John H. Wigmore, The Privilege Against Self-Crimination; Its History, 15 HARv. L. REV. 610 (1902), and was then revised across the editions of the treatise. See 8 Wigmore, supra, $\S 2250$, at 267 n.1.

Wigmore worked before the vast outpouring of research on the history of criminal law and procedure that has been published since World War II. The later scholarship has materially altered and enriched our view of many of the subjects that Wigmore confronted unaided. Wigmore worked almost entirely from the State Trials and the nominate law reports. He did not, for example, know the Old Bailey Sessions Papers, the extensive series of pamphlet trial "reports." See supra note 15.

As a general matter, Wigmore tended to project the origins of the rules of evidence further back than the historical record reasonably supports. The modern law of evidence is largely a product of the period from the mideighteenth to the midnineteenth centuries. Geoffrey Hazard has indicated that the attorney-client privilege, which Wigmore dated to Elizabethan sources, 8 WIGMORE, supra, $\S 2290$, at $542-43$, is effectively a product of the late eighteenth century. $C f$. Geoffrey C. Hazard, Jr., An Historical Perspective on the Attorney-Client Privilege, 66 CAL. L. REV. 1061, 1080 (1978). Wigmore places the modern hearsay rule in the late seventeenth century. See generally John H. Wigmore, The History of the Hearsay Rule, 17 HARV. L. REv. 437 (1904), which is substantially reproduced in 5 JOHN H. WIGMORE, EVIDENCE IN TRIALS AT 
ment. The common law courts are said to have recognized the privilege against self-incrimination in England in the middle of the seventeenth century, under the influence of the fall of the prerogative courts and the abolition of ex officio oath procedure in the ecclesiastical courts.

According to Wigmore, John Lilburne's "notorious agitation" against the Star Chamber in the years between 1637 and 1641 culminated in the statute of 1641 , abolishing the two most controversial courts, Star Chamber and High Commission. Then, "with a rush ... the 'ex officio' oath to answer criminal charges is swept away with them." ${ }^{26}$ Next - and this is the giant leap - Wigmore contends that the demise of ex officio oath procedure and of the prerogative courts that used that procedure affected the criminal procedure of the common law courts, by example. "With all this stir and emotion" of the fall of Star Chamber and High Commission and the suppression of ex officio oath procedure in the ecclesiastical courts, Wigmore writes, "a decided effect is produced, and is immediately communicated, naturally enough, to the common law courts." 127

I recommend suspending judgment on how "natural" it should have been to expect the common law courts, which had never employed the ex officio oath, to recast their criminal procedure for the purpose of implementing a notion that the common law courts had until then asserted only as a corrective against the quite incompatible ex officio oath procedure of detested noncommon law courts. This development may seem "natural" in the powerful light of hindsight from the entrenched privilege against self-incrimination of our modern law, but, as I have emphasized in Part I, an array of structural attributes of common law criminal procedure would have made the privilege unnatural and unworkable in the criminal trial of the later seventeenth century.

Wigmore's pithy argument continues: "Up to the last moment [in John Lilburne's struggle against the Star Chamber in the years 16371641, Lilburne] had never claimed the right to refuse absolutely to answer an incriminating question; he had merely claimed a proper proceeding of presentment or accusation. But now this once vital dis-

Common LAw § 1364, at 12-28 (James H. Chadbourn rev., Little, Brown 1974) (1940) (based extensively on the State Trials). For indications that the supposed hearsay rule was ignored well into the eighteenth century, see Langbein, supra note 8, at 301-02. See also Beattie, supra note 18 , at 232. I treat this topic extensively in a forthcoming article, John $\mathrm{H}$. Langbein, The Law of Evidence in the Eighteenth Century (Oct. 4, 1993) (unpublished manuscript, on file with author).

126. 8 WIGMORE, supra note $125, \S 2250$, at 289 (footnote omitted).

127. Id. (emphasis added). 
tinction comes to be ignored." 128 Wigmore thus argues that contemporaries confused two notions - on the one hand, the hostility to the practice of the noncommon law courts, especially Star Chamber and High Commission, that had been requiring the suspect to swear in advance to respond truthfully to questions about religious beliefs and political leanings; and, on the other hand, the expectation that someone being tried following indictment for the commission of a particular crime in a common law court would respond personally to the charges and the evidence adduced against him.129

Whether, as a practical matter, "this once vital distinction" was or could have been ignored seems highly unlikely. Speaking of the great moment, from 1641 and thereabouts, when the prerogative courts fell and when Parliament proscribed the use of ex officio oath procedure in the ecclesiastical courts, Wigmore writes:

It begins to be claimed, flatly, that no man is bound to incriminate himself on any charge (no matter how properly instituted) or in any court (not merely in the ecclesiastical or Star Chamber tribunals). Then this claim comes to be conceded by the judges ... even on occasions of great partisan excitement .... . By the end of Charles II's reign [that is, by 1685], there is no longer any doubt, in any court . . . 130 Wigmore's follower, Leonard Levy, echoes this claim. "By the early eighteenth century," says Levy, the privilege against self-incrimination "prevailed supreme" in the common law criminal trial. ${ }^{131}$

128. Id. (footnote omitted).

129. I am not alone in remarking on Wigmore's emphasis on serendipity in the common law's absorption of the privilege against self-incrimination. Macnair describes "Wigmore's classic account" as one that "saw the privilege as creeping in "by indirection' into the common law in the mid-seventeenth century in the wake of the fall of Star Chamber and High Commission, [i.e.,] almost by accident." Macnair, supra note 118, at 66 (quoting 8 WIGMORE, supra note 125, $\S 2250$, at 292).

130. 8 WIGMORE, supra note $125, \S 2250$, at $289-90$ (footnotes omitted). In the concluding footnote, Wigmore cites the 17 cases that I discuss infra in the text accompanying note 134.

131. LEVY, supra note 53, at 325. Levy tells what is, for practical purposes, a version of Wigmore's story. Levy singles out John Lilburne for adulation: "[M]ore than any other individual [Lilburne] was responsible for the acceptance of the principle that no person should be compelled to be a witness against himself in criminal cases." Id. at 313.

In truth, Lilburne was an insignificant figure in the development of the privilege. Lilburne was prosecuted criminally on several occasions over the years from the first proceedings against him in the Star Chamber under Charles I, 3 STATE TRIALS, supra note 4, at 1315 (1637), to his last common law trial in the Commonwealth period, 5 STATE TRIALS, supra note 4, at 407 (1653). Lilburne's reputation derives mainly from his spirited defense to treason charges brought against him during the Commonwealth period at a common law trial convened in 1649; the trial is extensively reported in 4 STATE TRIALS, supra note 4, at 1269 (1649). Lilburne raised two important themes in his defense - the need for defense counsel and the jury's power to engage in law nullifying - themes that would have a robust future. Lilburne complained incessantly about being denied the opportunity to consult counsel, id. at 1293-318, 1329-30, 1373-79, 1394-95, 1404, and he asserted the claim that juries are judges of law and fact. See, e.g., id. at 1379-81. The latter aspect of Lilburne's defense in the 1649 trial has been meticulously studied and related to the surrounding tract literature in GREEN, supra note 70, at 153-99.

Compared to these insistent themes of the trial, Lilburne's mention of the maxim about not 
Having explained in Part I why this familiar account ${ }^{132}$ of the appearance of the privilege against self-incrimination at common law is so improbable, I turn now to examine the sources that led Wigmore astray.

\section{Wigmore's Sources}

What, precisely, is the historical evidence that Wigmore adduces for his proposition that the common law privilege was broadly accepted ("no longer any doubt, in any court"133) by the 1680s? It consists of a forbiddingly long, double-column footnote, in which Wigmore collects citations to seventeen reported cases. ${ }^{134}$ These authorities turn out to supply weak support for Wigmore's proposition.

having to be a witness against oneself was quite peripheral. According to the verbatim of the State Trials report, Lilburne adverts to the idea twice. First, at the arraignment, not the trial, hence in a setting not strictly relevant to trial procedure, Lilburne announces that "by the Laws of England, I am not to answer to questions against or concerning myself." 4 STATE TRIALS, supra note 4, at 1292 . Keble, J., presiding, plays along, telling him, "You shall not be compelled." Id. at 1293.

Second, during the course of the trial, Keble has a handwritten document exhibited to Lilburne and asks him to acknowledge the handwriting. Lilburne refuses, saying he will not look at prosecution papers, "neither shall I answer to any questions that concern myself." Id. at 1340. A witness thereupon testified to Lilburne's authorship, which made it inconsequential that Lilburne had declined to stipulate to the point. Lilburne, however, linked up his refusal to answer the question with his larger strategy, which was to put the prosecution to its proofs. "I have said, Sir, prove it." Id. The exchange with Lilburne continues in this vein, the attorney general chiding him for not acknowledging his hand, Lilburne saying, "Sir, I deny nothing . . . but prove it first." Id. at 1341. Again: "I shall deny nothing I do. And yet I have read the Petition of Right, Sir, that teaches me to answer to no questions against or concerning myself, and I have read of the same to be practiced by Christ and his Apostles." Id. Lilburne was drawing not so much on the notion of a privilege against self-incrimination as upon the nascent concept of the prosecutor's burden of proof.

In this respect, Lilburne's claim was truly precocious, and it shows how the newer theory of the trial always lay close to the surface in the old. The old "accused speaks" trial could easily be converted to the "test the prosecution" trial if the defendant were willing to risk it. If this had been a homicide or a theft, the defendant would have hanged himself with these tactics. Lilburne's ploy was designed to put the prosecution on trial, and - without counsel - that risk could be taken only in a political case when the defendant had reason to suspect that he could evoke the sympathy of the jury.

Apart from these two asides, Lilburne responded at his trial to prosecution evidence and prosecution questioning as did other defendants of the age. For example, "I shall proceed on to answer your Proof to the Indictment ...." Id. at 1382. "In answer to whose testimony I return this ...." Id. at 1382. "[A]nd therefore I can answer to that nothing more than what I have said already." Id. at 1388. About certain books, he notes "I do not own [i.e., admit] a jot, a line, a word, a syllable of any one of them." Id. at 1389. "I hope I have so clearly and fully answered all and every of your proofs, that not any one thing sticks." Id. This behavior is quite difficult to reconcile with Levy's claim that Lilburne was insisting on a privilege against self-incrimination. In truth, like every other defendant of the age before defense counsel, Lilburne was obliged to defend himself in ways quite inconsistent with a privilege to remain silent.

132. See, for example, the compacted version of Wigmore's account in the leading textbook, Charles T. MCCORMICK, MCCORMICK ON Evidence $§ 114$, at 424 (John W. Strong ed., 4th ed. 1992).

133. 8 WIGMORE, supra note $125, \S 2250$, at 290 .

134. Id. at 290 n. 105 . 


\section{Civil Cases}

Five of the seventeen cases are civil cases and thus wholly inapposite. Four of these civil cases are from the court of Chancery. The parties were disputing whether discovery or other relief should be refused upon the basis of the familiar maxim of equitable jurisdiction that equity will not enforce a penalty or a forfeiture. ${ }^{135}$ The other civil case applies a similar principle to a prohibition action that was pending in a duchy court. ${ }^{136}$

\section{Criminal Cases}

The dozen remaining cases come from the State Trials and involve politically significant criminal charges. One is the report of a pretrial investigation that was dropped without trial. ${ }^{137}$ The remaining eleven involve criminal trials. In each, the defendant spoke vigorously and persistently to the merits in his own defense. What Wigmore identifies as evidence of the defendant invoking the privilege against self-incrimination is an isolated remark or exchange that occurs in a trial in which the defendant otherwise speaks constantly, utterly disregarding

135. African Co. v. Parish, 2 Vern. 244, 23 Eng. Rep. 758 (Ch. 1691); Bird v. Hardwicke, 1 Vern. 109, 23 Eng. Rep. 349 (Ch. 1682); Anon., 1 Vern. 60, 23 Eng. Rep. 310 (Ch. 1682); Penrice v. Parker, Rep. Temp Finch 75, 23 Eng. Rep. 40 (Ch. 1673).

For the flavor of these cases, consider the last, African Co. v. Parish, 2 Vern. 244, 23 Eng. Rep. 758 (Ch. 1691). The dispute concerned a charter party for the hire of a ship, which contained a noncompetition clause obliging the defendant to pay certain sums to the plaintiff "if the defendant traded in the goods the [plaintiff] company dealt in." 2 Vern. at 244, 23 Eng. Rep. at 758. The company sought discovery of the defendant to determine if he had traded in any such goods.

The defendant pleads the charter-party, by which it appears that the sums therein mentioned, were of double the value of the goods themselves, and so was in the nature of a penalty, and that he ought not to be compelled to make a discovery by answer touching the same, so as to subject himself to such penalties.

2 Vern. at 244, 23 Eng. Rep. at 758 . The court rejected the defense and ordered discovery. The cursory report explains: "The defendant must be bound by his own agreement, having agreed it shall be deducted out of the freight, he ought to discover..." 2 Vern. at 244, 23 Eng. Rep. at 758.

Macnair has now linked such Chancery sources to a larger set of equity cases, extending well back into Elizabethan times, that draw on canonist sources. Macnair, supra note 38, at 38-56; see also Macnair, supra note 118.

136. Firebrass' Case, 2 Salk. 550, 91 Eng. Rep. 465 (K.B. 1700) (granting prohibition against a bill of discovery in a duchy court touching the quantities of deer and timber that the chief ranger of a forest had taken).

137. Francis Jenkes, 6 STATE TRIALS, supra note 4, at 1189 (1676). The report concerns an investigation conducted by the king and his advisors at the Council board into remarks that Jenkes uttered in an election campaign speech on the hustings. Wigmore includes the cases in his list of supposed instances of the privilege against self-incrimination because Jenkes said at one point that he wished "to be excused all farther answer to such questions; since the law doth provide, that no man be put to answer to his own prejudice." Id. at 1194.

In truth, there was no recognition of the privilege against self-incrimination in the pretrial process until the nineteenth century. Levy acknowledges this point. See supra text accompanying note 68. 
any supposed privilege against self-incrimination. Only the powerful searchlight of hindsight makes these cases relevant to the history of the privilege. We may put this point in a different way by saying that, if the privilege had developed no further beyond the last of the trials that Wigmore cites, which occurred in 1685 , no scholar looking over these eleven cases could have concluded from such inconsequential gleanings that a doctrine resembling the privilege against self-incrimination was in force at common law.

a. Savaging the defendant. In five of Wigmore's eleven criminal trials, what is treated as evidence of the common law court's recognition of the privilege against self-incrimination is actually hostile behavior by the trial judge intended to disadvantage the defendant. In each case, the event that Wigmore cites is the judge's refusal to allow the defendant to cross-examine an accusing witness. ${ }^{138}$ For example, in the case of Nathanael Reading, ${ }^{139}$ one of the Popish Plot defendants, Reading attempted to ask the sinister prosecution witness Bedloe ${ }^{140}$ whether Bedloe was part of the supposed plot to burn Westminster. The presiding judge, Francis North, interferes, saying that "if you offer to ask him any question upon his oath, to make him accuse himself, we must oppose it." 141 Thus, North employed the slogan about not requiring a man to accuse himself for the purpose of shielding a prosecution witness against legitimate cross-examination. ${ }^{142}$ In the

138. See Titus Oates, 10 STATE TrIALS, supra note 4, at 1079, 1099, 1123 (1685); Thomas Rosewell, 10 STATE TrIals, supra note 4, at 147, 169 (1684); Earl of Castlemaine, 7 STATE TRIALS, supra note 4, at 1067, 1096 (1680); Richard Langhorn, 7 STATE TRIALS, supra note 4, at 417, 435 (1679); Nathanael Reading, 7 STATE TRIALS, supra note 4, at 259, 296 (1679). A student's seminar paper alerted me to the point developed above in text. See Mary D. Scott, The Dubious Existence of the Privilege against Self-Incrimination in the Seventeenth Century (1978) (unpublished seminar paper, University of Chicago Law School) (on file with author).

139. Nathanael Reading, 7 STATE TRIALS, supra note 4, at 259, 296.

140. Wigmore mistakenly says that Reading was trying to cross-examine Titus Oates. The actual witness was Oates' coconspirator, Bedloe. These revolting characters are the subject of a masterful book, John Kenyon, The PopIsh Plot (1972).

141. Nathanael Reading, 7 STATE TRIALS, supra note 4, at 296.

142. Recall that prosecution witnesses testified under oath while defense witnesses were forbidden from doing so and thus spoke unsworn, see supra notes $37-38$ and accompanying text, until the legislation of 1702 . See supra note 42 and accompanying text. The defendant spoke unsworn until 1898. See supra note 30 . North's reference to the oath of the prosecution witness may have been intended to invoke the distinction between sworn and unsworn witnesses. Under this interpretation, the defendant should not derive advantage from a witness testifying under oath, even when the testimony favorable to the defendant is elicited under cross-examination rather than under direct examination.

In separate correspondence, three scholars who read a prepublication draft of this essay (Christopher Allen, David Brown, and Michael Macnair) have cautioned that concern with oath in the pretrial process played a larger role in the development of the privilege against self-incrimination than our trial-centered literature has thus far recognized. Brown and Macnair each point to the murder trial of Sarah Malcolm, OBSP (Feb. 1733), at 90-91†, extracted in Langbein, supra note 8 , at $283 \mathrm{n} .58$, in which the court refused to allow the prosecution to use the JP's pretrial examination of the defendant because it had been taken on oath. The judge said: "If [the exami- 
sixth of Wigmore's cases, it was the prosecutor rather than the judge who attempted to hinder the cross-examination of a defense witness. ${ }^{143}$

In four of Wigmore's criminal cases, the defendants were victims of the baseless Popish Plot prosecutions. ${ }^{144}$ In five of Wigmore's cases, the judges whom he treats as supposedly vindicating the privilege against self-incrimination were the notorious Stuart bullies, Scroggs and Jefferies. ${ }^{145}$ In another of Wigmore's eleven criminal trial precedents, we find Jefferies serving as prosecuting counsel, pressing upon the court the maxim against "ask[ing] him any questions that may tend to accuse himself" for the purpose of interfering with the defendant's effort to conduct a cross-examination. ${ }^{146}$ Thus, most of Wigmore's authority for this supposed seventeenth-century breakthrough in defensive safeguard actually instances efforts by the subservient Stuart bench to disadvantage defendants in baseless political and religious persecutions.

b. Incidental claims. Apart from the cases previously examined, Wigmore points to three additional cases in which criminal defendants made episodic mention of an entitlement not to accuse oneself. ${ }^{147}$ In

nation] is upon Oath it cannot be read [at trial], for Persons are not to swear against themselves; all Examinations ought to be taken freely and voluntarily, and not upon Oath, and then we can read [th]em." OBSP (Feb. 1733), at 90-91. Beattie reports a comparable case from Surrey assizes in 1743, in which, according to the pamphlet report, the defendant's pretrial confession was offered:

[T] he confession was produced; but it being taken on oath, it could not be read. If it had been taken voluntarily it would have been admitted as good evidence; but the law supposes that an oath is a compulsion; and consequently that no man is obliged to swear against himself in cases where it affects his life.

BEATTIE, supra note 7, at 365-66 n.129 (extracting pamphlet report of 1743). Macnair directs attention to Dalton's JP manual dated 1619, see DALToN, supra note 7, at 273, in which Dalton explains "that the accused was to be examined without oath, citing nemo tenetur for this, and this statement was repeated by most subsequent authors; but the accused continued to be required to answer incriminating questions by the justices, though not on oath, until the nineteenth century." Macnair, supra note 118, at 79 n.99; see also BARLow, supra note 60; infra note 157.

143. William Viscount Stafford, 7 STAte Trials, supra note 4, at 1293, 1314 (1680).

144. William Viscount Stafford, 7 STATE TRIALS, supra note 4, at 1293; Earl of Castlemaine, 7 STATE TRIALS, supra note 4, at 1067; Richard Langhorn, 7 STATE Trials, supra note 4, at 417; Thomas Whitebread, 7 STATE TRIALS, supra note 4, at 311; Nathanael Reading, 7 STATE TRIALS, supra note 4, at 259.

On the Popish Plot, see generally KenYoN, supra note 140. For a succinct account, see STEPHEN, supra note 2, at 383-92 (concluding that, "in two years, and in connection with one transaction, six memorable failures of justice, involving the sacrifice of no less than fourteen innocent lives, occurred in trials held before the highest courts of judicature under a form of procedure closely resembling that which is still in force amongst us").

145. Thomas Whitebread, 7 STATE TRIALS, supra note 4, at 311 (Scroggs, Lord Chief Justice [hereinafter LCJ]); Titus Oates, 10 STATE TRIALS, supra note 4, at 1079 (Jefferies, LCJ); Thomas Rosewell, 10 STATE TRIALS, supra note 4, at 147 (Jefferies, LCJ); Earl of Castlemaine, 7 STATE TRIALS, supra note 4, at 1067 (Scroggs, LCJ); Richard Langhorn, 7 STATE TRIALS, supra note 4, at 417 (Scroggs, LCJ). Regarding Scroggs and Jefferies, see infra note 150.

146. Dr. Oliver Plunket, 8 STATE Trials, supra note 4, at 447, 480-81 (1681).

147. Thomas White, 7 State Trials, supra note 4, at 311, 361 (1679); Penn \& Mead, 6 
each of these cases, the incidental reliance upon the nemo tenetur maxim for not replying to a particular question is an isolated event during the course of a trial in which the defendant otherwise responds constantly to other questioning.

\section{Overview on Wigmore's Evidence}

The privilege against self-incrimination at common law did not exist during the period in which Wigmore thought he was seeing its origins. The successful campaign to topple the courts of Star Chamber and High Commission and to prevent the ecclesiastical courts from using ex officio oath procedure made a tremendous impression on contemporaries, just as Wigmore thought. But, while these events did indeed put the slogan nemo tenetur prodere seipsum into currency as an abstract principle or maxim worthy of respect, this maxim had no determinate meaning when applied to criminal procedure within the common law courts. That is why the bullying Stuart bench could turn the maxim upside down and use it as a club against the pathetic defendants in the Popish Plot cases, and that is why the defendants in a handful of other cases chanced to mention it in the course of proceedings that otherwise exhibit no fidelity to any privilege against selfincrimination.

\section{Wigmore's Reservations}

Having located what he thought to be the origins of the common law privilege in the seventeenth-century authorities, Wigmore had the marvelous good sense to record serious doubts about his own conclusion. His follower, Levy, displays no such circumspection. Levy depicts the modern Anglo-American privilege against self-incrimination as such an obvious historical inevitability that the only puzzle is to wonder why it took the dummies so long to see the light. ${ }^{148}$

\section{The Stuart Connection}

Wigmore was perplexed "that the privilege, thus established, comes into full recognition under the judges of the restored Stuarts, and not under the parliamentary reformers." 149 Wigmore sensed the irony inherent in his view of the development of the privilege against self-incrimination at common law. An event that has come to be un-

STATE Trials, supra note 4, at 951, 957 (1670); John Crook, 6 STATE Trials, supra note 4, at 201, 205 (1662); Adrian Scroop, 5 STATE TRIALS, supra note 4, at 1034, 1039 (1660).

148. For example, "[a]lthough the legal profession customarily refers to the right against self-incrimination as a 'privilege,' I call it a 'right' because it is one." LEVY, supra note 53, at vii.

149. 8 WIGMORE, supra note $125, \S 2250$, at 290. 
derstood in historical perspective as among the most distinctive attributes of defensive safeguard in the whole of our criminal procedural tradition was, on Wigmore's view of it, the handiwork of the notoriously craven late-Stuart bench. The judges who supposedly created the privilege at common law were Scroggs, Jefferies, and their brethren - men whose names are synonymous with subservience to the crown and murderous unfairness to criminal defendants. ${ }^{150}$ I find it difficult to imagine that a group of judges who displayed such hostility toward criminal defendants would simultaneously have been so alert to recognize and enforce a novel and dissonant measure of defensive safeguard.

Levy, unlike Wigmore, was untroubled to find himself celebrating the spectacle of the late-Stuart judiciary serving as the engine that crafted the privilege. Indeed, it is the Popish Plot trials, which were as manifest a persecution of innocent people as ever occurred at common law, that move Levy to exult in "how scrupulously the courts adhered to the right against self-incrimination."151

\section{Judicial Indifference}

Wigmore noticed how tentative the supposed privilege against selfincrimination was in the hands of the very judges who supposedly recognized it. Referring to the behavior of the bench in the seventeenthcentury State Trials, his primary resource, Wigmore remarked that

150. On Scroggs and Jefferies, see BIOGRAPHICAL DictionaRY OF THE COMMON LAW 27477, 466-67 (A.W.B. Simpson ed., 1984); 6 WILlIAM HOLdSWORTH, A HistoRY OF ENGLISH LAW 504-08, 527-30 (2d ed. 1937); compare the adulatory G.W. KEETON, LORD CHANCELLOR JEFFREYS AND THE STUART CAUSE 24-25 (1965). On the judicial politics of the era, see Alfred F. Havighurst, James II and the Twelve Men in Scarlet, 69 LAW Q. REV. 522 (1953); Alfred F. Havighurst, The Judiciary and Politics in the Reign of Charles II, 66 LAW Q. REV. 62, 229 (1950).

151. LEVY, supra note 53, at 318 . Levy seems to think that the privilege against self-incrimination was part of a broader movement of safeguard in the seventeenth century. He admits that the "adversary system in criminal proceedings had always been a one-sided affair, with the crown enjoying advantages denied to the accused. Procedural reforms of the very late seventeenth century redressed the imbalance, giving to the accused a greater measure of parity." Id. at 320-21. He mentions compulsory process in 1696 and 1701 and copy of the indictment and right to counsel in 1696 and thereafter. Id. at 321-23. "Accordingly, by the early eighteenth century both judicial and statutory alterations in procedure made it possible for a defendant to present his defense through witnesses and by counsel. As a result ... he was no longer obliged to speak out personally in order to get his story before the jury ...." Id. at 323. Thus, claims Levy, "[b]y the early eighteenth century, the [privilege against self incrimination] prevailed supreme in all [trial] proceedings ...." Id. at 325 .

Levy is correct to notice that the Treason Act of 1696 entailed a fundamental movement toward more balanced criminal procedure. What he overlooks is the highly exceptional character of the Act. The reforms applied to a minuscule subset of cases, prosecutions for treason. The object of the 1696 legislation was to do criminal procedural business as usual except for treason. See supra text accompanying notes $41,49-50,86-91$. The momentous change for the history of ordinary criminal procedure was the allowance of defense counsel, which occurred as a trickle in the 1730 s and which does not seem to have unsettled the basic "accused speaks" trial until well into the second half of the eighteenth century. See supra text accompanying notes 93-96. 
the supposed privilege against self-incrimination "remained not much more than a bare rule of law, which the judges would recognize on demand. The spirit of it was wanting in them. The old habit of questioning and urging the accused died hard - did not disappear, indeed, until the 1700 s had begun."152 This is Wigmore's way of noticing that, even in the handful of cases that contain supposed authority for his view that there was a seventeenth-century privilege against selfincrimination, the evidence is at most an isolated reference to the privilege in the course of a trial at which the defendant otherwise replied routinely to the accusations against him.

\section{Failure of Constitutionalization}

When the age of safeguard in common law criminal procedure actually dawned, the English displayed a peculiar disinterest in securing the privilege against self-incrimination among their landmark safeguards. As Wigmore observed, "[i]n all the parliamentary remonstrances and petitions and declarations that preceded the expulsion of the Stuarts, [the privilege against self-incrimination] does not anywhere appear." 153 The privilege "was not worth mentioning to the English constitution-menders of 1689," that is, in the Bill of Rights of 1689.154 I would add in a similar vein that it is even more revealing that the determined Whig reformers of the $1690 \mathrm{~s}$, who drafted that great catalog of procedural safeguards for the Treason Act of 1696, ${ }^{155}$ found no room to include the supposed privilege against self-incrimination among the protections that they valued.

\section{E. Overview on a Historical Error}

How could a historical writer so sensitive to the sources and to the subject as Wigmore have erred by a century in identifying the origins of the privilege against self-incrimination? Wigmore did not fabricate. The nemo tenatur slogan did indeed gain currency during the TudorStuart constitutional struggles. Wigmore in effect traced some of the history of the use of the slogan. The key insight, however, is that the slogan did not make the privilege; it was the privilege, which developed much later, that absorbed and perpetuated the slogan. The ancestry of the privilege has been mistakenly projected backwards upon the slogan, whereas the privilege against self-incrimination in common

152. 8 WIGMORE, supra note $125, \S 2250$, at 291 (footnote omitted).

153. Id. at 292 (footnote omitted).

154. Id.

155. 7 \& 8 Will. 3 , ch. 3; see also supra text accompanying notes 84-92 (discussing the Act). 
law criminal procedure was, in truth, the achievement of defense counsel in the late eighteenth and early nineteenth centuries.

Without defense counsel, a criminal defendant's right to remain silent was the right to forfeit any defense; indeed, in a system that emphasized capital punishment, the right to remain silent was literally the right to commit suicide. Only when defense counsel succeeded in restructuring the criminal trial to make it possible to silence the accused did it also become possible to fashion the true privilege against self-incrimination at common law.

\section{CONCLUSION}

I have been tempted to speak in a shorthand of sorts, in order to make the pithy claim that the theme of this essay is that there was no privilege against self-incrimination in common law criminal procedure during the early modern epoch - until, that is, the late eighteenth century. Formulating the claim in this way almost captures what has been shown, yet it would neglect an important strand. The core value of the privilege against self-incrimination was indeed on the lips of those whose words have found their way into the conventional but misguided historical account of the supposed Tudor-Stuart origins of the privilege.

The better way to encapsulate the theme of this essay is not to say that there was no privilege, but rather to recognize that the structure of criminal procedure in the early modern epoch made it impossible to implement the privilege. The "accused speaks" criminal trial stood in perpetual tension with any notion of a right to remain silent. The privilege against self-incrimination became functional only as a consequence of the revolutionary reconstruction of the criminal trial worked by the advent of defense counsel and adversary criminal procedure. The privilege as we understand it is an artifact of the adversary system of criminal procedure. The error has been to expect to find the privilege in operation before the adversary system was in place.

Across the centuries the privilege against self-incrimination has changed character profoundly, from the original privilege not to accuse oneself to the modern privilege not to respond or to testify. Many policies have come to be associated with the privilege against self-incrimination. Indeed, Wigmore enumerated a full dozen for his trea- 
tise. ${ }^{156}$ They range from the prohibition on torturing the accused ${ }^{157}$ (a reform that had been achieved before the first traces of the privilege at common law ${ }^{158}$ ), to the modern American rule forbidding adverse comment on the accused's silence ${ }^{159}$ (a rule so recent, ${ }^{160}$ historically speaking, that the ink is still wet). But the core value of the privilege, the accused's right not to speak, presupposes an effective right to have another speak in the accused's stead. In our legal history, that right was the achievement of the later eighteenth and early nineteenth centuries.

156. 8 WIGMORE, supra note $125, \S 2251$, at $297,310-18$.

157. Barlow's JP manual of 1745 makes the connection between not torturing and the nemo tenetur maxim:

The Law of England is a Law of Mercy, and does not use the Rack or Torture to compel Criminals to accuse themselves; since these Methods are cruel, and at the same Time uncertain, as being rather Trials of the Strength and Hardiness of the Sufferer, than any Proof of the Truth, by the Confession which is extorted from him, or by his Perseverance in his Denial. I take it to be for the same Reason, that it does not call upon the Criminal to answer upon Oath. For, this might serve instead of the Rack, to the Consciences of some Men, although they have been guilty of Offences. And the Proof could not all be depended on, unless it was a Confession; and it would be hard, and unequal to rack a Man's Conscience with the Religion of an Oath, and make his Discovery tend to his Condemnation, but not allow his Denial on Oath to have any Weight towards his Exculpation or Acquittal.... The Law has therefore wisely and mercifully laid down this Maxim, Nemo tenetur seipsum prodere.

BARLow, supra note 60, at 189.

158. The English authorities used torture in at least 81 cases over the years 1540 to 1640 .

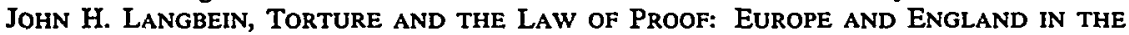
ANCIEN REGIME 81-128 (1977). The practice ceased in the 1640s, with no evident invocation of any privilege against self-incrimination. Id. at 135-36.

159. Griffin v. California, 380 U.S. 609 (1965).

160. It is also controversial. See, e.g., WALTER V. SchaEfer, The Suspect and Society: Criminal Procedure and Converging Constitutional Doctrine 71 (1967). 